\title{
GUERRA ECONÓMICA Y COMERCIO EUROPEO EN ESPAÑA, 1624-1674. LAS GRANDES REPRESALIAS Y LA LUCHA CONTRA EL CONTRABANDO ${ }^{1}$
}

\author{
por \\ ÁNGel Alloza APARICIO \\ UNED, Madrid
}

RESUMEN: Por medio del examen de las principales represalias que se efectuaron en el siglo XVII contra franceses, ingleses y bolandeses, $y$ de los embargos generales a que dieron lugar, este artículo contribuye a esclarecer el impacto real de las medidas de guerra económica adoptadas por la Monarquía Católica contra sus adversarios más perseverantes en el dominio del comercio mundial. A tal fin el trabajo explora las raíces medievales del derecho de represalia, de marcado carácter "privado", y su transformación ya en época moderna en una práctica muy extendida entre los gobiernos de Europa Occidental, objeto de una profunda reformulación normativa.

Palabras Clave: Comercio. Embargos. Guerra Económica. España. Siglo XVII.

ABSTRACT: Through an analysis of the main reprisals carried out against French, English and Dutch in the seventeenth century, and the general embargoes to which they gave rise, this study addresses the impact of the economic war measures adopted by Spanish Hapsburgs against their most stubborn adversaries in the struggle for global commercial power. The article also explores the medieval roots of the law of reprisal, of a marked "private» character, and its transformation during the early modern period into a extended normative practice widely used by Western European governments.

1 Este trabajo se inscribe dentro del proyecto Escomarin (BHA2000-0183-C02-01) del Programa Nacional de Promoción General del Conocimiento. Agradezco a Carlos Martínez Shaw, José María Iñurritegui, Juan Antonio Sánchez Belén y Pablo Fernández Albaladejo su apoyo en la inves- tigación que llevo a cabo sobre el comercio europeo en España durante el siglo XVII. 
KEY WORDS: Trade. Embargoes. Economic War. Spain. Seventeenth Century.

\section{INTRODUCCIÓN.}

Entre mediados del siglo XVI y comienzos del siguiente, algunos arbitristas e importantes representantes del gobierno de la Monarquía Hispánica se empeñaron en convertir en máxima la idea según la cual sin el concurso de las exportaciones y el comercio español algunas economías europeas como la inglesa o la francesa acabarían colapsando. En verdad, al monopolio español del metal precioso y del suministro de índigo, cochinilla, tabaco y palo campeche se unió, tras la agregación de Portugal, el de la sal de calidad, un producto de suma importancia para las industrias pesqueras de Holanda, Escandinavia y el tráfico holandés en el Báltico. A este dominio se añadía el del azúcar de Brasil y el ya legendario de la lana merina de Castilla, tan estimada en Italia, Flandes, Norte de Francia e Inglaterra. En tales circunstancias, como ha apuntado el profesor Israel, no resulta extraño que existieran expectativas de dominar las rutas, mercados y productos en el Norte de Europa, así como de aislar a los enemigos apartándoles de su comercio².

Frente a este esquema que todavía afirmaba la supremacía comercial española durante la primera mitad del siglo XVII, algunas voces de la historiografía reciente, como ya hicieran muchos arbitristas del momento, han opuesto que la presión ejercida por la Monarquía Católica contra sus adversarios en el Norte de Europa fue mínima e ineficaz, y que tal superioridad — si es que alguna vez existió - fue efímera, a consecuencia de una balanza comercial desfavorable, unas políticas mercantilistas débiles y escasamente protectoras, y una invasión progresiva de mercaderes extranjeros en el comercio exterior español, lo que les permitió controlar el destino y financiación de los intercambios, hacerse con el mercado de fletes y seguros, y extender finalmente el uso de sus propias flotas en vez de las españolas ${ }^{3}$.

Por añadidura, esta historiografía sostiene que apenas se hizo nada para frenar una tendencia, al parecer inexorable, que llevaba a España a la periferia

2 ISRael, J., La República Holandesa y el Mundo Hispánico, 1606-1661. Madrid, 1997; del mismo autor Dutch Primacy in the World Trade, 1585-1740. Oxford, 1989.

3 Sobre la política noratlántica de Felipe IV ver ALCALÁ-ZAmORA, J., España, Flandes y el mar del Norte (1618-1639). Barcelona, 1975; la debilidad de las políticas mercantilistas en MARCOS MARTín, A., España en los siglos XVI, XVII y XVIII. Economía y Sociedad. Barcelona, 2000, págs. 100-180 y 378-403. Por lo que se refiere a los arbitristas y otros escritores influyentes del momento véase LARraz, J., La época del mercantilismo en Castilla. Salamanca, 2000. Colmeiro, M., Historia de la Economía Política Española. (1863) edición de la Fundación Banco Exterior, tomo II, Madrid, 1988; Hamilton, E. J., El florecimiento del capitalismo. Ensayos de Historia Económica. Madrid, 1984, págs. 185-206.

Hispania, LXV/1, núm. 219 (2005) 227-280 
del naciente sistema económico mundial. Marcos Martín ha apuntado que los intentos de desarrollar una política mercantilista quedaron en papel mojado no sólo debido a la diversidad de estructuras económicas en el interior de la península, sobre todo en los planos monetario, aduanero y fiscal; sino también de resultas de la debilidad que sentían los comerciantes españoles por los beneficios especulativos obtenidos con la exportación de materias primas, en vez de arriesgar en la economía productiva de su entorno ${ }^{4}$. Con similar orientación, Felipe Ruiz Martín explicó cómo los españoles de comienzos del siglo XVII comprendieron pronto que el creciente poder de ingleses y holandeses derivaba de su ascendente economía, por lo que dedujeron que atacando ésta debilitarían aquél. En opinión del autor, se asestaron certeros golpes, pero al dedicarse tan sólo a impedir el crecimiento enemigo, y no a fomentar el propio, los esfuerzos y éxitos carecieron de porvenir. ${ }^{5}$ Este cuadro está pintado sobre un fondo de quiebra financiera permanente, y de grandes deudas contraídas por los sucesivos monarcas con banqueros y comerciantes extranjeros, las cuales obligaron a otorgarles importantes concesiones en los mercados español y americano ${ }^{6}$.

Por estas razones coinciden algunos especialistas en que unos pocos embargos y secuestros de naves y mercancías constituyeron todo el arsenal de guerra económica que pudo permitirse la Monarquía Católica, toda vez que España no se encontraba en condiciones de resistir mucho tiempo los bloqueos comerciales que ella misma imponía, debido a su gran dependencia de productos transportados en exclusiva por sus adversarios, desde pertrechos navales y arboladura, hasta determinadas manufacturas muy demandadas en los mercados español y americano 7 . Sin embargo, si las medidas de guerra económica que se adoptaron en el transcurso de todos aquellos años fueron ineficaces, e incluso contraproducentes para la economía española, no resulta fácil explicar porqué hubo tanto empeño puesto en ellas por parte del gobierno de Madrid, y porqué se dieron con tanta reiteración si apenas daban frutos, máxime tras constatar que algunas represalias originaron duraderos embargos generales, como los efectuados contra holandeses, franceses o ingleses, que destruyeron una y otra vez las bases de su comercio en territorio español.

\footnotetext{
${ }^{4}$ Marcos Martín, A., España en los siglos XVI, XVII y XVIII. op. cit., págs. 126-129.

5 Ruiz MARTín, F., "La etapa marítima de las guerras de religión. Bloqueos y contrabloqueos», Estudios de Historia Moderna, III (1953), págs. 181-214.

6 Domínguez Ortiz, A., Política y Hacienda de Felipe IV. Madrid, 1960. Sobre los banqueros extranjeros en España, ver BROENS, N., Monarquía y Capital Mercantil: Felipe IV y las Redes Comerciales Portuguesas (1627-1635). Madrid, 1989; BoYajIAN, J.C., Portuguese Bankers at the Court of Spain, 1626-1650. New Jersey, 1983. Véase asimismo Álvarez Nogal, C., El crédito de la Monarquía Hispánica en el reinado de Felipe IV. Ávila, 1997.

7 AlCAlá-Zamora, J., España, Flandes y el mar del Norte. Op. cit. págs. 182-184; para la segunda mitad del siglo XVI ver GómEZ-CENTURIÓN, C., Felipe II, la empresa de Inglaterra y el comercio septentrional (1566-1609). Madrid, 1988.
} 
Sólo la represalia efectuada en 1635 contra los franceses expulsó del comercio ibérico a centenas de súbditos del Rey Cristianísimo que contrataban en los principales puertos y plazas españolas, además de embargar los bienes y pertenencias de varios miles más de franceses que residían en la península. La represalia iniciada en 1656 contra los ingleses aniquiló la colonia británica residente en ambas Castillas, Aragón, Navarra, Reino de Valencia e islas Canarias. En éstas últimas se embargó y expulsó a cerca de un centenar de prestamistas y comerciantes ingleses que por entonces moraban en ellas.

Algunos estudios han concluido que las licencias especiales y el contrabando minimizaron, e incluso llegaron a neutralizar, el impacto de las medidas de guerra económica adoptadas por Felipe IV y Carlos II, pero en realidad tales afirmaciones carecen de evidencia empírica suficiente, ya que el contrabando apenas se ha estudiado, y el sistema de licencias especiales, si bien es cierto dejaba sin efecto las prohibiciones de comercio, mantenía abastecidos los mercados en la medida de lo posible y allegaba recursos a la siempre necesitada Real Hacienda $^{8}$. Especialistas como Jonathan Israel han resaltado el papel central de los embargos en la política española, concluyendo que - al menos en el caso holandés estudiado por el autor- la campaña de corso, unida a los embargos decretados contra sus buques y mercancías, tuvieron grandes repercusiones en la economía neerlandesa?.

Con el objeto de esclarecer el impacto real de la guerra económica protagonizada por la Monarquía Católica contra ingleses y franceses entre 1624 y 1674 , este trabajo identifica y analiza las principales represalias comerciales, y los embargos generales a que dieron lugar, efectuados contra los súbditos de aquellas coronas como consecuencia de los rompimientos, en su mayoría bélicos, surgidos en 1625 contra ingleses y franceses simultáneamente, en 1635 contra franceses, en 1656 contra ingleses, y en 1667 y 1674 de nuevo contra franceses. El largo conflicto hispano-neerlandés resulta bien conocido gracias a los trabajos citados de Israel, Alcalá-Zamora, así como los de Manuel Herrero y otros ${ }^{10}$, por lo que

8 Recientes e interesantes estudios sobre el contrabando y las licencias especiales revelan la complejidad de una materia que demanda a todas luces mayor atención. Véanse por ejemplo los de LÓPEZ BELINCHÓN, B. J., «Sacar la sustancia del reino». Comercio, contrabando y conversos portugueses, 1621-1640» Hispania, 209 (2001) págs. 1.017-1.050; CARRASCO VÁZQUEZ, J., "Contrabando, moneda y espionaje (el negocio del vellón:1606-1620)» Hispania, 197 (1997) págs. 1.0811.105; SANZ AYÁN, C., "Negociadores y capitales holandeses en los sistemas de abastecimiento de pertrechos navales de la Monarquía Hispánica durante el siglo XVII» Hispania, 188 (1992) págs. 915-945; Herrero SÁNCHEZ, Manuel, «La política de embargos y el contrabando de productos de lujo en Madrid (1635-1673). Sociedad cortesana y dependencia de los mercados internacionales», Hispania, 201 (1999) págs. 171-191.

9 ISRAEL, J., «A conflict of empires: Spain and the Netherlands, 1618-1648» y «Spain, the spanish embargos, and the struggle for the mastery of world trade, 1585-1660", en Empires and entrepots. The Dutch, the Spanish Monarchy and the Jews, 1585-1713. London, 1990. págs. 1-41 y 189-212.

10 Herrero SÁnhez, M., El Acercamiento Hispano-neerlandés(1648-1678). Madrid, 2000; López MARTín, I., «Embargo and Protectionist Policies in Late Sixteenth and Early Seventeenth- 
se ha optado por no reproducir aquí sus consecuencias, aunque sí se contemplan sus repercusiones más que notables sobre el tráfico europeo, el contrabando y la propia política exterior de la Monarquía.

Antes de proceder al análisis de las represalias, resulta conveniente examinar si quiera brevemente el origen y significado jurídico de las mismas, y cómo lo interpretaron posteriormente los juristas españoles del siglo XVI y comienzos del siguiente, lo que permitirá observar cómo el uso de este derecho de origen medieval, muy extendido entonces entre particulares, se fue transformando a lo largo de la edad moderna en una práctica muy utilizada por los gobernantes, a su vez perfeccionada y adaptada a las nuevas circunstancias. Al objeto de comprobar la eficacia de los bloqueos comerciales derivados de las represalias, el trabajo desarrollará asimismo algunos aspectos relevantes de la lucha contra el contrabando desplegada por los veedores de la Junta del Almirantazgo entre 1625 y 1647 , y finalmente unas reflexiones basadas en datos cuantitativos sobre el sistema de las licencias especiales para importar mercancías de contrabando.

\section{EL DERECHO DE REPRESALIA.}

La toma de represalias constituía un derecho que se arrogaban los soberanos para causarse igual o mayor daño que el que habían recibido, y que a menudo incluía la retención de los bienes del estado (o de sus individuos) con el cual se estaba en guerra o en un conflicto grave. En la Edad Media, este derecho a tomar represalias se concedía generalmente a particulares - por la autoridad soberana a la cual estaban sujetos- para tratar de recuperar, aunque fuera mediante el uso de la fuerza, sus bienes o el equivalente a ellos, sobre un extranjero o sus conciudadanos, al no haber conseguido justicia por las vías legales de su país. De modo que se trataba de un derecho público, soberano, pero también de una regalía ${ }^{11}$.

Algunos tratadistas españoles, como Baltasar de Ayala o Luis de Molina, creyeron ver el origen de este derecho en la antigüedad, al que los griegos llamaban androlepsia y los romanos impignorationes ${ }^{12}$. Sin embargo, algunos autores del siglo XIX negaron que el carácter de guerra privada y de reivindicaciones

Century Hispano-Dutch Relations in the Western Mediterranean", Mediterranean Studies, VII (1998), págs. 191-219.

${ }^{11}$ Un examen de este derecho de origen medieval, en De MAS LATRIe, R., Du Droit de Marque ou Droit de représailles au Moyen Age. París, 1866. Unas notas sobre esta noción en el derecho contemporáneo, en RUIPÉREZ JuAREZ, J., La definición de represalias en el derecho internacional vigente. Salamanca, 1963.

12 La carta de represalia, según René de Mas Latrie, es un acto público mediante el cual un soberano concede a sus ciudadanos la facultad de usar de este privilegio excepcional, cuya definición en los textos aparece de distintas formas: Marca, Represaliae, Pignorationes, Pignora, Queminae, Cambium y Laudes. 
particulares con que se identificaba la represalia medieval pudiera existir siquiera en el derecho romano, donde primaba el principio de no solidaridad. Para éstos últimos sí podría provenir, en cambio, de los pueblos germánicos, en cuyas normas sobre la guerra privada reinaba un espíritu de solidaridad que obligaba a los miembros de una misma familia a defenderse mutuamente. De todos modos, fue en la Edad Media donde el derecho de represalia adquirió una notable trascendencia, al convertirse en el medio de solucionar conflictos entre reinos, repúblicas o ciudades sin tener que llegar a la guerra.

El peligro que entrañaba su carácter privado le llevó a ser objeto de una regulación importante, acomodándose de forma simultánea a la incipiente reglamentación que sobre el comercio marítimo comenzaba a adoptarse en Europa. La frecuencia con que se repetían las represalias en la baja Edad Media motivó la aparición de un buen número de tratados sobre su práctica (Bártolo, Canibus, Garat...) los cuales prescribían unas normas que básicamente se han seguido en las represalias acaecidas en la época moderna. En síntesis, tales normas exigían la existencia de una autoridad legítima para dictar la represalia, generalmente la máxima autoridad de un estado o territorio, aquélla que podía declarar la guerra; la existencia asimismo de una causa justa, como la violación de un derecho de cierta gravedad por parte de extranjeros; y finalmente la denegación de justicia por parte del país de origen de los que causaron el agravio, lo cual implicaba que había habido solicitud previa de reparo por vía judicial ${ }^{13}$.

Pese a su práctica extendida y su regulación normativa, ni los juristas medievales ni los doctores de la época moderna fueron capaces de justificar moralmente y de forma satisfactoria el ultraje que suponía el hacer pagar a un inocente por un culpable. Hoy se afirma que las represalias, tanto en tiempo de guerra como en tiempo de paz, implican una violación del derecho, una excepción dolosa al principio general de equidad según el cual un inocente no debe sufrir por un culpable. Sin embargo, los autores del siglo XVI y XVII trataron de justificar jurídicamente el derecho a las represalias con unos argumentos a veces inverosímiles, yendo mucho más lejos incluso de lo que habían ido los primeros formuladores y pioneros en su práctica medieval. Tanto es así que en la baja Edad Media y temprana Edad Moderna se trató con frecuencia de impedir semejantes ultrajes, unas veces dictando represalias exclusivamente contra aquellos sujetos del gobierno que habían declinado administrar justicia -dejando a un lado a los ciudadanos inocentes de ese estado- y en otras protegiendo a los extranjeros residentes mediante su exclusión de los embargos: Carlos V de Francia mandó que los forasteros autorizados por él a permanecer en Francia no pudieran sufrir represalias, ni en sus bienes ni en sus personas. En Inglaterra se ordenó en el año 1215 que los bienes de extranjeros estuvieran exentos de

${ }^{13}$ Las relaciones comerciales entre Inglaterra y España a fines del siglo XV están plagadas de conflictos producidos por robos y violencias, los cuales desembocaron las más de las veces en represalias que, a su vez, generaron nuevos litigios. Véase CAUNEDo DEL POTro, B., La actividad de los mercaderes ingleses en Castilla (1475-1492). Madrid, 1984.

Hispania, LXV/1, núm. 219 (2005) 227-280 
represalia, si bien en 1353 se aprobó la posibilidad de embargarles en caso de que a sus naturales se les denegase justicia en otros países ${ }^{14}$.

En otras ocasiones, con objeto de atenuar los efectos perversos de tan extrema medida, se trató de garantizar la afluencia de abastos de primera necesidad mediante su exclusión de las represalias. Las leyes en Castilla también limitaron el uso de esta práctica sobre inocentes en diversas normas redactadas en los siglos XIV y XV, prohibiendo prendar, como forma de represalia, navíos y mercancías por deudas que pudieran tener sus dueños, o prendar a los mercaderes por las deudas que pudieran tener sus vecinos o sus ciudades de origen ${ }^{15}$.

Para Luis de Molina, como para Francisco de Vitoria, las represalias eran lícitas cuando reunían las condiciones esenciales, esto es, autoridad legítima para dictarlas, causa justa, y denegación de justicia. Sin embargo, la cuestión sobre el hecho de que las sufrieran los inocentes por los culpables no parece que les preocupase demasiado, al postular que en el transcurso de una guerra era lícito arrebatar al enemigo sus propiedades, aunque se tratase de inocentes ciudadanos o extranjeros residentes en ese país, ya que con ello se sancionaba al estado que no castigó a los verdaderos culpables. Molina fue un poco más lejos al afirmar que todos los súbditos de un estado enemigo, incluso los inocentes, podían ser lícitamente sometidos a la esclavitud ${ }^{16}$.

Baltasar de Ayala también creía lícito recurrir a las represalias cuando se daban los requisitos, pero al menos admitía que se trataba de una cuestión muy controvertida en lo que a su inclusión o exclusión en el derecho se refería, teniendo en cuenta que era inicuo y ajeno a justicia infligir una pena a un inocente por una culpa de otro, pues la pena sigue al autor del crimen. Ayala encontraba que en determinadas causas, y para utilidad de la república, y con el fin de que los hombres se abstuvieran más de cometer delitos, podía la ley humana castigar con penas pecuniarias, como la confiscación de bienes, incluso a aquéllos que no delinquieron ${ }^{17}$. Algunas décadas más adelante, un buen conocedor de los conflictos internacionales y de la pugna por el monopolio de los océanos, como era Hugo Grocio, escribía que así como la legítima defensa y la propia guerra habían logrado encontrar asiento en el derecho internacional a pesar de la moral evangélica, las represalias no dejaban de representar una suerte de escándalo, por el hecho de que un inocente sufriese las faltas de un compatriota de quien lo desconocía todo ${ }^{18}$.

${ }^{14}$ De Mas Latrie, R., Du Droit De Marque. op. cit., págs. 9-19.

15 Novísima ReCOPILACIÓN DE las LeYeS de España (en adelante Nov. Rec.) Libro XI, Título XXXI.

16 FraGa, M., Luis de Molina y el derecho de la guerra. Cambados, 1947, págs. 156-163.

17 BALTASAR DE AYALA, Del Derecho y de los oficios de la guerra. Capítulo IV: de las pignoraciones, que el vulgo llama represalias. Ver también PerAlta, J., Baltasar de Ayala y el derecho de la guerra, Madrid, 1964.

18 Haggenmacher, P., Grotius et la doctrine de la guerre juste. Paris, 1983, págs. 168 y 169. 
A pesar de sus controvertidas consecuencias, ya en la segunda mitad del siglo XVI - si no antes - algunos tratados de paz y comercio firmados entre monarquías europeas prescribieron el derecho a tomar represalias en caso de denegación de justicia, por lo cual dejó de tratarse de una práctica hostil de dudosa legalidad y pasó a constituir una norma legal sancionada en importantes acuerdos. El Tratado de Cateau-Cambrésis (1559) registró que en caso de denegación de justicia, Francia podía asegurarse la satisfacción de ese rechazo y cobrar sobre los bienes de los españoles, sin que estas represalias pudieran ser consideradas actos de hostilidad. La misma cláusula se encuentra también en tratados posteriores, desde Vervins en 1598, hasta Ryswick en 1697.

Si las represalias y los embargos a que daban lugar torpedeaban con especial puntería el comercio extranjero en tierra firme y puertos de mar, tratando de perjudicar a los estados adversarios por medio de sus súbditos, el mar fue testigo de otro de los instrumentos de guerra económica más poderosos en manos de los gobernantes, el cual estaba representado por la actividad corsaria. El corso general sólo podía capturar navíos enemigos o neutrales que transportasen contrabando de guerra, pero el denominado corso «particular o de represalias» se efectuaba tanto en tiempo de guerra como en tiempo de paz. De hecho, la actividad corsaria no cesó ni un solo instante en el periodo objeto de este estudio ${ }^{19}$. El no reconocimiento a Portugal y España por parte de Inglaterra y Holanda de la posesión efectiva de los territorios de ultramar, sobre los que ejercía un monopolio comercial que excluía a los demás estados, fue motivo de disputas y conflictos permanentes que derivaron las más de las veces en actividades corsarias y actos de pillaje sin más, unas veces con patentes de corso, pero otras sin ellas.

Con el argumento de que el mar y el aire estaban a disposición de todos para uso común, los ingleses postularon la libertad de comercio y navegación por los océanos, que eran de todos y para todos. Estos son los argumentos que más tarde emplearía el propio Grocio en Mare Liberum (1609) tomados a su vez de Francisco de Vitoria y Vázquez de Menchaca. Lo curioso de semejante formulación reside en que unas décadas más adelante, cuando Inglaterra comenzó a señorear los mares, presentó el Mare Clausum (1635) — redactado por Seldencon argumentos nada conciliadores: «mare liberum... must be answered with a defense of mare clausum: not so much by discourses, as by the lauder language of a powerful navy» ${ }^{20}$.

19 Sobre el corso, su definición, estructura y actividad, ver OTERo LANA, E., Los corsarios españoles durante la decadencia de los Austrias. Madrid, 1992 y STRADLING, R., La Armada de Flandes. Politica naval española y guerra europea, 1568-1668. Madrid, 1992.

${ }^{20}$ La cita proviene del prólogo de Luis García Arias a Hugo Grocio: De la libertad de los mares. Edición del Centro de Estudios Constitucionales, Madrid, 1979, pág. 21. Sobre la posición de los diferentes estados europeos en torno a la cuestión de la libertad de los mares, ver FAL, G., $E l$ principio de la libertad de los mares. Práctica de los estados de 1493 a 1648. Madrid, 1974. Véase también TUC, R., The rights of war and peace. Political Thought and the international order from Grotius to Kant. Oxford, 2001; Schmitr, C., El nomos de la tierra (en el Derecho de Gentes del Jus Publicum Euro-

Hispania, LXV/1, núm. 219 (2005) 227-280 
Sólo estas premisas podían justificar por sí solas el despacho de patentes de corso, aunque en realidad éstas se venían dando desde antiguo con cierta frecuencia y ante las más variadas circunstancias. Stradling ha afirmado que los estados europeos del momento consideraban que existiendo una situación legal de guerra las propiedades de sus súbditos quedaban sometidas a un riesgo ilimitado. El rompimiento de Holanda significó que todo el comercio con la República, salvo en el periodo de tregua, se considerase contrabando, y por tanto objetivo de los corsarios. Este autor ha calculado que hasta 1607 la actividad corsaria de particulares y del Almirantazgo de los Países Bajos logró capturar cerca de 50 barcos al año considerados buena presa, si bien a partir de 1621 (año del fin de la tregua) los apresamientos anuales alcanzaron una media cercana a los 200 barcos $^{21}$.

\section{LA REPRESALIA DE 1625 CONTRA LOS FRANCESES.}

El tenso ambiente registrado entre España y Francia tras apoyar Luis XIII a Venecia y Saboya contra Génova, se enrareció aún más a comienzos de 1625 cuando el Duque de Guisa concibió la idea de interceptar un envío inminente de dinero de Barcelona a Génova, con la excusa de que la escolta de ese transporte, compuesta por 20 galeras y 4.000 hombres, inquietaba la seguridad de la Provenza. Su intento sin embargo no consistía sino en impedir que la plata llegase a su destino, al objeto de enfrentar a Felipe IV con problemas de liquidez en Flandes, como revela la carta que el mismo Guisa remitió a mediados de enero de ese año a Luis XIII, pidiéndole permiso para llevar a cabo su plan. El proyecto fue descubierto en Barcelona, y el envío de moneda, alrededor de un millón de ducados, quedó suspendido temporalmente ${ }^{22}$.

En el mes de marzo de ese mismo año tres laúdes* genoveses cargados también con dinero fueron arrastrados por una tormenta a la costa francesa, muy cerca de Marsella, donde una galera del gobernador de Provenza procedió a su arresto. Guisa hablaba de un cargamento de 84 cajas con 20.000 reales cada una, los embajadores de Felipe IV de 160.000 ducados, si bien sus verdaderos propietarios, entre los que se encontraba Bartolomé Spínola, sólo reclamaban 128.963 ducados. Muy poco tiempo después, los franceses tomaron por presa a la altura de Calais una galizabra con más de 40.000 ducados pertene-

paeum) Madrid, 1979; y sobre el declive de Castilla y Portugal en Asia acosados por holandeses e ingleses en la zona, Valladares, R., Castilla y Portugal en Asia (1580-1680). Declive imperial y adaptación. Louvain, 2001.

${ }^{21}$ Stradling, La Armada de Flandes., op. cit., págs. 265-306.

22 GiRARD, Albert, "La saisie des biens des franÇais en Espagne en 1625», Revue d'Histoire economique et sociale, 19 (1931), págs. 297-315. Del mismo autor, Le Commerce Français a Séville et Cadix au temps des Habsbourg. París, 1932, edición de 1967, págs. 63 y siguientes.

* Barcas de ocho remos. 
cientes a Octavio Centurión, Esteban Spínola, Vicencio Squarzafigo, Juan Jerónimo Spínola, Pablo y Agustín Justinianos, Antonio Balbi, Lelio Imbrea y Julio César Escazuola ${ }^{23}$.

El incidente de Marsella causó un enorme efecto en España, ya que si bien el dinero estaba embarcado a nombre de un genovés llamado Batchon, pertenecía a españoles y genoveses protegidos de Felipe IV, por lo menos el que iba registrado. Por si fuera poco, los arrestos efectuados tenían la aprobación de Luis XIII, aunque posteriormente el monarca se desmarcara afirmando que él no aprobaba ni desaprobaba nada hasta recibir las demandas de los interesados y estudiar los informes respectivos. Según Albert Girard, los propietarios del caudal ofrecieron a Olivares la mitad de la suma secuestrada si utilizaba su influencia para recuperar la plata. Pero no les hacía falta ofrecer semejantes incentivos, ya que en realidad faltó tiempo a Felipe IV para solicitar la devolución del dinero y amenazar con represalias por el valor equivalente a lo incautado si no retornaban de inmediato el dinero secuestrado.

Ante la negativa del Cristianísimo, el día dos de abril de 1625 Felipe IV ordenó el embargo de los bienes de franceses que se encontrasen en los puertos españoles, hasta conseguir los 160.000 ducados confiscados en Marsella, lo cual podía ser desastroso para los mercaderes galos, ya que según el embajador Du Farguis, sus bienes en España podían alcanzar fácilmente la cifra de cuatro millones de ducados en oro. Éstos se quejaron al Rey de Francia, pero Guisa mantenía que las barcas eran genovesas, mientras en Madrid se afirmaba que el dinero era parte español y parte genovés. La respuesta de Luis XIII no se hizo esperar, y a fines de abril prohibió el comercio con España y ordenó el embargo de españoles y genoveses que se encontrasen en puertos franceses ${ }^{24}$. Para mayo de 1625 el Cristianísimo había extendido la confiscación a portugueses, granadinos, milaneses y napolitanos, y ordenado por vía de represalia que los bienes confiscados se depositasen hasta nueva orden. Esta respuesta del Monarca francés originó que el embargo en España se hiciese general, no sólo hasta conseguir 160.000 ducados como se había planeado al principio ${ }^{25}$.

El embajador Du Farguis estaba convencido de que la política hostil de Olivares contra comerciantes y marinos franceses se realizaba como castigo por introducir en España mercancías holandesas de contrabando. Pero lo cierto es

23 Archivo General de Simancas (en adelante AGS), Estado-K, legajo 1.433.

${ }^{24} \mathrm{La}$ prohibición del comercio se produjo en 29 de abril. Biblioteca Nacional de Madrid (en adelante BNM), Ms. 2.357, fols. 54-55.

${ }^{25}$ Archivo Histórico Nacional (en adelante AHN) Consejos, legajo 7.269. «El duque de Guisa a cuyo cargo están las galeras del rey de Francia, tomó los otros días con ellas 160.000 ducados que iban a Génova de vasallos míos, y aliados a esta Corona, y porque aunque en Francia se ha pedido restitución no se hace, he resuelto que se haga represalia de los bienes de naturales de aquel reino que hubiere en estos, embargando todos los que se hallaren en esta corte, y en todas las demás ciudades, villas y lugares de ellas». Ver también ABreu BerTODANO, J. A., Colección de los tratados de paz de España. Primera parte, 1621-1626. Madrid, 1746, año 1625.

Hispania, LXV/1, núm. 219 (2005) 227-280 
que no sólo introducían contrabando, sino que también sacaban fraudulentamente dinero de la península. En marzo de 1625 Felipe IV volvió a comisionar a Juan de Pedroso, de los Consejos de Hacienda y Guerra, para que investigase un descamino de 126.670 reales y cinco barras de plata descubierto en Sanlúcar de Barrameda, y que era conducido a una nao de franceses. En el transcurso de la investigación, el propio Rey le informó de que aquella no era la única saca que se había descubierto recientemente, por lo que le rogó que las investigase todas $^{26}$. Los franceses, por su parte, mandaron realizar informes sobre las vejaciones que sufrían los mercaderes a manos de las autoridades españolas ${ }^{27}$.

Este proceso de represalia que se abría, como en posteriores embargos que se examinarán en este mismo estudio, se desarrolló de acuerdo con unas instrucciones básicas ${ }^{28}$, muy inconcretas si se comparan con las de represalias ulteriores, así como bajo la autoridad de una junta formada para la ocasión, constituida por el marqués de Montesclaros, experto en comercio exterior y miembro de los consejos de Hacienda y Estado, el duque de Alburquerque, el conde de Monterrey y don Juan de Villela. Las instrucciones comenzaban con el inicio mismo de los embargos, los cuales habían de comenzarse en igual fecha en todas las localidades, el 31 de mayo, a fin coger por sorpresa a los franceses y evitar que ocultasen sus bienes. Por supuesto, algunos de los más acaudalados ya habían sido avisados por su embajador de la inminencia de un embargo general.

No obstante, y a pesar de los avisos que el embajador du Farguis había dado a sus compatriotas para que pusiesen a buen recaudo sus capitales, el embargo se llevó a cabo y en el transcurso de muy pocos meses se obtuvo la enorme suma de 7.392 .999 reales, más todos aquellos bienes «en ser», navíos y

26 AGS, Guerra Antigua, legajo 917.

27 Como las que cita GIRARD «Mèmoire sur les vexations que les marchands franÇais souffrent en Espagne sur le fait du commerce» y «La différence qu'il y a du traitement que les franÇais recoivent en Espagne et Flandres d'avec celui que les espagnol et flamands recoivent en France». GIRARD, Le Commerce Français. op. cit., p. 62.

${ }^{28} \mathrm{El}$ embargo, advertía «el papel secreto" o instrucción, había de hacerse universalmente de todo género de bienes y mercancías, y otros cualesquier efectos que tuviesen los franceses, también sus bienes muebles y raíces; asegurando bien las haciendas en los aposentos, tiendas o lugares donde las tuviesen, dejando personas de confianza en ellos, y tomando luego las llaves de las puertas donde quedasen depositados. Había asimismo que apoderarse de los libros y papeles, guardándolos sin examinarlos hasta que se diese orden en contrario. En los puertos de mar la represalia ya había sido iniciada con anterioridad por orden del Rey, vía Consejo de estado, lo que se advertía para que las nuevas instrucciones no chocasen con lo ya publicado. Se ordenó asimismo que se guardasen y custodiasen con mucha atención los bienes incautados, sin necesidad de hacer inventarios, para que no faltase «ni un alfiler», de manera que los franceses «no pudiesen formar queja de que por medio de este embargo, ni de los alguaciles ni guardas, se les ha quitado nada». Además del arresto de los bienes, la instrucción se utilizó para investigar a la colonia francesa en Madrid, averiguar las armas que poseían sus miembros, el trato que tenían entre sí, sus lugares de reunión y residencia. En los decomisos habían de escribir los nombres, provincias y lugares de donde eran naturales los propietarios de los bienes decomisados, así como el tiempo que llevaban residiendo en España y los compatriotas con quienes tenían tratos en Francia. AHN, Consejos, legajo 7.269. 
mercaderías que no habían sido tasados ni valuados a la fecha de remitir los informes a la junta de represalias. El remitido desde Navarra, por ejemplo, sólo incluía el dinero, ya que el resto de las haciendas embargadas no venían valuadas; en Oviedo había tres navíos franceses sin tasar; en Cataluña dos saetías, y en casi todos los puertos existían bienes y embarcaciones arrestadas pero sin valuar.

\section{RELACIÓN DE LO QUE IMPORTA LO EMBARGADO \\ EN BIENES DE FRANCESES, 1626.}

\begin{tabular}{lr} 
PROCEDENCIA & IMPORTE \\
\hline & (en reales) \\
Jerez & 85.742 \\
Cádiz & 287.900 \\
Ronda & 4.917 \\
Málaga & 33.956 \\
Navarra & 901.152 \\
Oviedo & 6.461 \\
Guipúzcoa & 96.551 \\
Bilbao & 97.609 \\
Sanlúcar & 208.914 \\
Ayamonte & 14.593 \\
Valencia & 3.357 .280 \\
Sevilla & 503.645 \\
Aragón & 1.024 .870 \\
Mallorca & 139.608 \\
Cataluña & 220.000 \\
Lisboa & 409.801 \\
\hline
\end{tabular}

FUENTE: AGS, Estado-K, Legajos 1.433 y 1.434 .

En Galicia, el duque de Aramayona embargó en los puertos del Reino siete navichuelos y una charrúa; uno de ellos con 96 quintales de hierro, otro con 150 fanegas de cal, y en el resto halló 28 toneladas de trigo, 54 moyos de sal, y 650.000 reis (16.250 reales). En Vizcaya había arrestados ocho navíos cargados de hierro pertenecientes a franceses y españoles. En Portugal los embargos se elevaron a 409.801 reales (incluyendo 12 navíos) pero también había mercancías por valor de 82.594 reales que estaban cargadas para Francia por portugueses e italianos, los cuales las reclamaban por ser suyas. En Santander no hubo nada que embargar.

Los valores aportados en el cuadro adjunto indican que las áreas fronterizas con Francia tenían un comercio muy fluido con el país vecino, tanto o más que

Hispania, LXV/1, núm. 219 (2005) 227-280 
Andalucía, y la región mediterránea mucho mayor todavía que la fachada atlántica, si bien es cierto que — como destacara Albert Girard - sólo en Andalucía podrían haberse embargado no menos de dos millones de ducados pertenecientes a franceses, de no haber tenido noticia previa de la represalia. $\mathrm{Na}$ varra recaudó nada menos que 90.000 ducados, Aragón alcanzó los cien mil, el Reino de Valencia recaudó 300.000 ducados de valor, siendo con mucha diferencia la mayor cantidad aprehendida en la Península. Estas cifras contrastan fuertemente con las registradas en los puertos de Andalucía, pero hay que tener en cuenta que la partida de Aragón, por ejemplo, incluye los bienes raíces y las deudas que los naturales tenían contraídas con franceses, mientras en el sur se secuestraron los navíos y sus cargas, pero de los bienes de aquellos que residían y comerciaban en la región sólo se embargaron pequeñas cantidades.

El duque de Medina-Sidonia, en carta fechada en 13 de abril de 1625, afirmó quie antes de que hubiese llegado el despacho con la orden de represalia, los franceses ya sabían que ésta se iba a producir, por lo que se anticipó y embargó cuatro navíos dentro de la barra de Sanlúcar cuyos cargamentos de ropa, sin contar los propios navíos, valían 60.000 ducados. Como era de esperar, los cónsules de Sevilla representaron los daños que los embargos causaban al comercio; el administrador de-los almojarifazgos de dicha ciudad también protestó y escribió al duque diciéndole que los embargos habían de entenderse únicamente con los pasajeros franceses, pero no con los residentes. El mismo Olivares admitió el daño que el comercio iba a sufrir con la represalia, especialmente cuando la flota de Nueva España estaba a punto de partir, y criticó la anticipación de Medina-Sidonia. Para colmo, el Almirantazgo puso de manifiesto que algunos de los bienes embargados por el duque en Sanlúcar no eran de franceses, sino de españoles que los traían bajo nombre francés por seguridad, al ser Francia un país neutral ${ }^{29}$.

El Consejo de estado discutió sobre estos problemas, pero finalmente convino en transmitir a Felipe IV la necesidad de seguir adelante con los embargos, porque los franceses se mostraban cada vez más provocadores. Por lo que se refería a la opinión de los consulados, los consejeros hicieron saber al Rey que éstos siempre estarían a favor de a contratación, «como Vuestra Majestad ha de estarlo siempre de parte de la justicia» remacharon, y no se debían perdonar bajo ningún concepto las confiscaciones sufridas por los españoles en Francia, las cuales - informaba el conde de Castrillo- se habían extendido a sus bienes raíces e incluso a algunas rentas eclesiásticas, como las del monasterio de Roncesvalles. En cambio, Castrillo admitía que los embargos en España estaban perjudicando enormemente a los navarros, a quienes sería fuerza «dar satisfacción de lo que está embargado de franceses». Para su desagrado, la idea de indemnizar a navarros embargados en Francia fue rechazada por el Consejo ${ }^{30}$.

\footnotetext{
${ }^{29}$ AGS, Estado-K, legajo 1.433

${ }^{30}$ Ibid.
} 
Todos estos problemas ocasionados por los embargos fueron atendidos en el Consejo de estado, aunque no a todos ellos se les dio la solución que demandaban sus peticionarios. En San Sebastián, el decomiso de los navíos que transportaban trigo para la ciudad elevó las protestas por el desabasto de pan que ocasionaba, viéndose obligados a reivindicar unos privilegios especiales que permitían a los franceses llevarles trigo aun en tiempo de guerra. Montesclaros aprobó el abastecimiento por franceses, pero únicamente de pescado. También en Bilbao se pidió permiso para comerciar con Francia y abastecerse de lo necesario, que no sólo eran productos del mar, sino también trigo y otros granos, además de brea, alquitrán, mástiles y jarcia. Tras arduas discusiones, el Consejo acabó permitiendo la entrada de todos estos géneros, con la única condición de que en retorno los navíos franceses se llevasen frutos de la tierra ${ }^{31}$. El Virrey de Aragón escribió a Felipe IV representándole los disgustos que acusaban los aragoneses ante la falta de comercio con Francia, y no sólo debido a la escasez de abastos necesarios, sino sobre todo a la falta del dinero que el comercio dejaba en impuestos, razón por la cual rogó se tolerase al menos el tráfico con Bearne, ya que ni el Rey de Francia lo tenía prohibido. A petición del Conde de Chinchón, no se admitió la propuesta ${ }^{32}$.

El tratado de Monzón, por el cual se resolvió temporalmente el asunto de la Valtelina, también significó el final de la represalia; sin embargo, la ambigüedad de lo capitulado en este respecto fue objeto de duras disputas que a punto estuvieron de provocar un nuevo enfrentamiento. El capítulo diecisiete de la segunda redacción del acuerdo, fechado en 5 de marzo de 1626, establecía que los embargos hechos por los dos reyes sobre los súbditos de uno y otro fuesen levantados, ajustando previamente la satisfacción de los laúdes de Marsella y la galizabra de Calais, la cual debería ser resuelta por los embajadores. Aún así, la ejecución del tratado, que no fue firmado por Luis XIII hasta mayo, se llevaría más de un año todavía.

Sólo en las cuestiones de comercio bilateral, las exigencias francesas excedían en mucho a lo capitulado en anteriores acuerdos. Los capítulos que el conde de Roxepot propuso por orden particular de Luis XIII a Felipe IV en diciembre de 1626, eran a todas luces inadmisibles. Entre otras cuestiones, el diplomático pedía que sus vasallos quedasen libres de las penas por saca de moneda del Reino, y que sólo perdieran lo que se les aprehendiese (como erróneamente creía que se hacía con ingleses y holandeses en tiempo de paz y tregua); pedía asimismo facultad para eludir lo dispuesto por el Almirantazgo (porque según sus criterios se oponía a la libertad de comercio); permiso para navegar sus mercancías en buques de rebeldes; evitar las visitas y la obligación de portar testimonios de procedencia de las mercancías; poder los comerciantes tener sus libros en lengua francesa, así como otros privilegios no menos llamativos pero

${ }^{31}$ Ibid.

32 AGS, Guerra Antigua, legajo 3.149

Hispania, LXV/1, núm. 219 (2005) 227-280 
algo más discutibles. El Almirantazgo examinó los capítulos del embajador y rechazó casi todos ellos. Incluso antes que dejar impunes a los sacadores de plata y oro, el organismo postuló la conveniencia de agravar las penas por saca, o por lo menos ejecutar las que había, pues importaba guardar el tesoro del Reino, ya que en su opinión era «el nervio principal que sustenta la República y conserva la Monarquía» ${ }^{33}$.

Por lo que respecta a la represalia, a fines de diciembre de 1626 el marqués de Mirabel asentó con los ministros franceses la forma de llevar a cabo los desembargos. Con la promesa incluida del Rey Cristianísimo, Richelieu acordó con Mirabel pagar el dinero de Marsella y Calais en el plazo de un año, con la seguridad de que si en el plazo fijado no devolvían el dinero, España podría efectuar nuevos embargos sin que por ello pudiera hacer lo mismo el Rey de Francia. Este preacuerdo fue examinado en la junta de represalias y suscitó múltiples dudas, en particular porque el Cristianísimo no daba su palabra sobre el pago: se limitaba a decir que la daría más delante, sin especificar cuando.

Montesclaros apuntó ante los miembros de la junta que lo realmente asentado era que una vez levantados en Francia los embargos o contrarrepresalias, se levantarían asimismo en España, salvo la cantidad equivalente a lo secuestrado en Calais y Marsella, hasta que ésta se devolviese; y que todo esto le parecía bien. En cambio, el marqués estimó la conveniencia de dar cuenta de este acuerdo de aplazar el pago a los interesados antes de firmarlo, pues la realidad era que desde la firma del tratado de Monzón habían transcurrido 10 meses y Luis XIII no había restituido nada; al contrario, había declarado que antes de devolver el dinero a sus dueños habían de acudir a Francia a pedir justicia, y en caso de no alcanzarla estarían autorizados a resarcirse de los bienes de los franceses en Génova, cosa imposible de todo punto. Montesclaros, afinando su agudo olfato jurídico-político, pensó que la obligación de hacer justicia a los interesados sobre las haciendas tomadas a marselleses y otros fránceses no debía entenderse en caso de guerra rota, sino sólo hasta la fecha de inicio de la guerra entre Génova, Francia y Saboya, y después de firmada la paz.

El Duque de Alburquerque, el Conde de Monterrey y don Juan de Villela aprobaron lo expuesto por Montesclaros, si bien Villela insistió en la necesidad de dar buen trato a los genoveses para que cobrasen sus haciendas, pero sin preocuparse en exceso por el asunto, ya que él tenía entendido que «el dinero que les tomaron en Marsella iba la mayor parte por registrar y de razón lo tenían perdido...» La cuestión, como se ve, tenía su enjundia, por lo que las discusiones pasaron al Consejo de estado en febrero de 1627. Reunido éste, don Pedro de Toledo mostró su malestar porque lo que pedían últimamente los embajadores era distinto de lo que habían capitulado en Aranjuez, sin la aquiescencia de Richelieu, y que el Rey de Francia ni siquiera había querido confirmar. Por otra parte, Pedro de Toledo opinaba que lo que ahora se trataba debería ser hablado

${ }^{33}$ AGS, Estado, legajo 2.646.

Hispania, LXV/1, núm. 219 (2005) 227-280 
sólo después de la entrega de la Valtelina. Montesclaros también mostró su inquietud porque veía que las pretensiones de los franceses eran detener y embarazar la ejecución de los acuerdos, al objeto «de pretender de nuevo como si empezara otra negociación distinta, de manera que no había cosa fija ni estable». Lamentaba que los capítulos asentados con Francia estaban firmados por su embajador Monsieur Du Farguis, y sin embargo ahora pretendían removerlos por unas conversaciones que tuvieron con el marqués de Mirabel. A pesar de los inconvenientes generados por Francia, en Madrid todos tenían claro que sólo cuando el Cristianísimo devolviera el dinero secuestrado se alzarían los embargos. Y así lo aprobó el resto de los consejeros: Hinojosa, Monterrey, el padre confesor, Duarte de Portugal, Diego de Mejía y el conde de Chinchón.

La postura de Felipe IV era a todas luces más flexible. El Rey consideraba muy conveniente que los franceses hallasen buena acogida y facilidad en España, sobre todo en unos momentos en los cuales los ingleses trataban de irritarles. El asunto de la Valtelina, que constituía lo principal del tratado, estaba muy adelantado, y eso - según el Monarca- no podía perderse de ningún modo. La propuesta de Felipe IV fue que se publicara el desembargo, pero que no se ejecutase en tanto en cuanto no se devolviese el dinero secuestrado; además, de los bienes embargados a franceses se podría restituir disimuladamente a sus dueños el dinero de los laúdes, pero «sin hacer mención a nada de esto». El día dos de marzo de 1627 el Rey envió una carta a Juan de Villela comunicándole que se había tomado asiento con Francia para la restitución del dinero secuestrado durante las guerras de Italia, y que una vez concertadas las paces sólo restaba alzar todos los embargos, por lo que le pedía que por medio de la junta de represalias se diesen las órdenes y despachos oportunos para restituir a sus dueños las haciendas decomisadas ${ }^{34}$.

El plan de ordenar los desembargos pero no ejecutarlos hasta conseguir la devolución total del dinero secuestrado en Marsella y Calais fue muy bien interpretado por los ministros españoles, lo cual irritó enormemente a los embajadores franceses, que constataban cómo a pesar de las órdenes que mandaban desembargar, los ministros no las ejecutaban. El 16 de marzo de 1627 don Fernando de Toledo recibió la orden de desembargar los bienes de franceses que se habían incautado en Portugal, así como la de sacar de la cárcel de Lisboa a un portugués llamado Pedro de Baeza, que era fiador de un francés hasta en cantidad de 26.000 reales. Los embajadores ordinario y extraordinario de Francia se quejaron de don Fernando de Toledo por no cumplir las órdenes que recibía, y pedían que la ejecución de ellas se cometiese a otra persona. Estos mismos diplomáticos redactaron memoriales protestando por la actitud del Virrey de Cataluña y del corregidor de Jerez, con los mismos motivos ${ }^{35}$.

\footnotetext{
${ }^{34}$ AGS, Estado-K legajo 1.433.

35 Por añadidura, Fernando de Toledo se había valido para diferentes fines de 40.000 ducados procedidos de bienes de franceses que a la fecha del desembargo no estaba en condiciones de devol-

Hispania, LXV/1, núm. 219 (2005) 227-280
} 


\section{REPRESALIA CONTRA INGLESES EN 1625.}

En agosto de 1625 Carlos I de Inglaterra firmó un tratado con las Provincias Unidas acordando unir sus fuerzas navales para invadir Cádiz, quemar los navíos de guerra españoles y apoderarse del tesoro que debían traer las flotas de Indias. La historiografía clásica interpretó la invasión como un golpe de resentimiento e insatisfacción del Estuardo a consecuencia del fracaso de su plan dirigido a establecer unas relaciones más fluidas con la Monarquía Hispánica por medio de su casamiento con la hermana de Felipe IV ${ }^{36}$. Tras la negativa obtenida en Madrid en la primavera de 1623, el todavía Príncipe de Gales —acompañado por el duque de Buckingham y un grupo de parlamentarios ingleses - inició en.Westminster una ofensiva que consistía en hacer virar su lucha contra el exceso de privilegios con que se beneficiaban ciertas compañías, como la formada por los Merchant Adventurers, hacia una política abiertamente anti-española, aunque se realizase oficialmente sólo con la intención de fomentar la liberalización del comercio ${ }^{37}$.

La poderosa Armada inglesa avistada en Cádiz en noviembre de 1625, compuesta por 106 naves y 14.000 hombres, fue repelida después de ocho días de lucha en aguas del Atlántico. En diciembre de aquel mismo año, con la excusa de que el comercio se había convertido en muy peligroso, Carlos I prohibió a sus vasallos el trato en los dominios del Rey Católico, así como en los de la Infanta doña Isabel Clara Eugenia, bajo pena de confiscación de navíos y mercancías. La agresión inglesa provocó la paralización del comercio entre ambas coronas, que se prolongaría hasta 1630; también originó la toma de represalias por parte de Felipe IV, materializada con la confiscación y venta de los barcos ingleses que se aprehendieron en algunos puertos de la Península Ibérica, especialmente en Andalucía y Portugal. La orden de confiscar fue dada en Monzón el 19 de marzo de 1626, y en ella el monarca instaba al Almirantazgo a aprehender y embargar los navíos ingleses, así como las mercancías que vinieran en ellos, debido a las hostilidades que habían hecho, como el rompimiento ejecutado sin aviso, ni causa ni pretexto justo, y sin tiempo para que los súbditos de la Monarquía Hispánica sacasen de Inglaterra sus haciendas ${ }^{38}$.

ver. AGS, Estado, legajo 2.983. No obstante, existe constancia de que ya a fines de 1626 se procedió a desembargar algunos bienes de franceses, como por ejemplo los del doctor francés Pedro Micon, residente en Madrid desde 1610. Ver AHN, Consejos, libro 1.211 (539-540).

36 Sobre este aspecto concreto puede verse RODRíGUEZ MONIINO, R., Razón de estado y dogmatismo religioso en la España del siglo XVII. Negociaciones bispano-inglesas de 1623. Madrid, 1976.

37 Abreu Bertodano, J. A., Colección de los tratados de paz. Año 1625. Información sobre la política anti-española en el Parlamento, en BRENNER, R., Merchants and Revolution. Commercial Change, Political Conflict, and London's Overseas Traders, 1550-1653. Cambridge, 1993. págs. 243-269.

38 La Pragmática del Rey de Inglaterra prohibiendo el comercio de sus vasallos con España, en BNM, Ms. 2.357, f. 75. Las medidas adoptadas por Felipe IV, en ABREU BERTODANO, op. cit. año de 1626; Servicio Histórico Militar (en adelante SHM) Fondo Histórico. Rollo 8, vol. 30, así como en AGS, Guerra y Marina, legajo 939 (sin foliar). 
La represalia en Andalucía había comenzado unos pocos meses antes de que se publicara la orden de confiscación en marzo de 1626, pues don Fadrique de Toledo - Capitán General de la Armada del Mar Océano- ya había embargado en Málaga, a fines de noviembre de 1625, ocho navíos ingleses cargados con casi 4.000 quintales bacalao. Del pescado se destinaron 160 quintales para dar ración a las tripulaciones de los navíos arrestados, 300 a diferentes conventos de religiosos de la ciudad de Málaga, y finalmente 3.436 quintales se condujeron a la alhóndiga de la ciudad para proceder a su venta, a razón de 45 reales el quintal, y cuyo importe, unido al procedido de la venta de los barcos, produjo la nada despreciable suma de 259.490 reales en dinero efectivo, y algunas otras mercancías que quedaban en depósito al tiempo de hacer la relación del embargo. ${ }^{39}$ Del dinero procedido de la venta de los navíos y el bacalao, se enviaron a Madrid 226.400 reales, y se empleó el resto en la paga de los guardias de los navíos, el trabajo de transporte del pescado, así como en diversos gastos menudos, alquiler de almacenes y correos.

NAVÍOS INGLESES EMBARGADOS EN MÁLAGA. REPRESALIA DE 1625.

\begin{tabular}{lcl} 
Nombre Del Navío & $\begin{array}{c}\text { PrECIO DE } \\
\text { VENTA (REALES) }\end{array}$ & COMPRADOR \\
\hline Buena Ventura & 6.600 & Julio Bautista Caro \\
La Flor & 2.420 & Cristóbal Millán \\
Antelop & 4.620 & Cristóbal Millán \\
El Dragón & 13.000 & Adrián Páez \\
La Dádiva & 12.771 & Adrián Páez \\
El Don de Dios & 14.000 & Jaques Avellano \\
La Fortuna & 3.500 & Luis de San Martín \\
El Pedro & - & Pasa a la Armada \\
\hline
\end{tabular}

FUENTE: AGS, Estado, legajo 4.126. Los buques venían cargados de bacalao y algunos de ellos ya tenían carga de regreso compuesta de vino, pasas y otros frutos que también fueron embargados.

Tras las primeras confiscaciones, el conocido comerciante flamenco Adrian Paez inició un pleito contra la veeduría del contrabando de Málaga, sin duda ignorando que el litigio iba a prolongarse durante 23 años. El mercader representó ser dueño del navío la Dádiva, valorado en 1.161 ducados, y de su cargamento de bacalao, y con objeto de no perder el barco ni la carga, y poder continuar su actividad comercial, Paez readquirió el buque mediante el abono de una fianza. De nuevo bajo su propiedad, le hizo zarpar el día 19 de febrero

${ }^{39}$ AGS, Estado, legajo 4.126 (sin foliar).

Hispania, LXV/1, núm. 219 (2005) 227-280 
de 1626 cargado con vino y pasas, no obstante las órdenes en contrario que se le habían dado, así como las diligencias, protestas y notificaciones que se le hicieron para impedirlo. Por su incumplimiento se procesó criminalmente al flamenco y se le puso en la cárcel, hasta que Fadrique de Toledo le dio libertad bajo una nueva fianza. Entre tanto, Paez también había adquirido por 13.000 reales el navío nombrado el Dragón. Al cabo de 23 años, y tras sendas sentencias de vista y de revista a su favor, una cédula de Su Majestad publicada en agosto de 1647 mandó pagar a Adrian Paez la suma de 13.000 ducados de vellón, de la veeduría del contrabando de la ciudad de Málaga, por las cantidades de bacalao y vino que se le habían embargado en dos navíos ingleses en $1625^{40}$.

Continuaron produciéndose denuncias de similar naturaleza, si bien en ningún momento llegaron a impedir que la represalia continuara su curso. El navío llamado El Pedio, embargado en enero de 1626 en Málaga, iba cargado con plomo, pescado y otras mercancías, cuyo valor resultó también bastante elevado. Su carga de 2.358 quintales de bacalao, vendidos la mayoría de ellos a 64 reales el quintal, por estar en muy buenas condiciones, alcanzó una cifra cercana a 150.000 reales, a la que se sumaron 33.000 reales procedidos de la venta del propio navío, comprado por un flamenco de nombre español llamado Lorenzo de Lepe, más lo que pudiera resultar de la venta de 607 quintales de plomo que asimismo traía el barco. En Cartagena se embargaron dos navíos cargados también con pescado salado, de cuya venta remitió el corregidor de dicha ciudad 142.816 reales a los fucares ${ }^{41}$.

Al mismo tiempo que se producían los embargos de navíos ingleses en Andalucía, don Fernando Alvia de Castro hacía confiscar en Portugal diferentes naves que llegaban a Lisboa cargadas con bayetas, algunas de ellas procedentes de Hamburgo. La habitual inquina de los portugueses hacia los castellanos, esta vez camuflada en problemas de competencias y jurisdicción, repercutió seriamente en la represalia, pues cuando Alvia de Castro fue a proceder a la venta de los paños, los gobernadores lusos lo impidieron, tratando de consignar por todos los medios las manufacturas incautadas a las personas que estaban interesadas en ellas, ante lo cual la junta de represalias, constituida por Mendo da Mota, don Juan de Villela, el conde Monterrey y el marqués de Montesclaros, pidió al Consejo de Portugal que instruyese a sus gobernadores sobre el modo de proceder en los embargos, de forma que no entorpeciesen a los veedores del contrabando.

Por su parte, algunos de aquellos mercaderes interesados en las bayetas, depositadas en la alfándiga de la ciudad por los ministros lusos, remitieron un memorial a Felipe IV explicándole que las mercancías enviadas por sus correspondientes en Hamburgo habían salido de puerto 40 días antes de que se publicase el bando prohibiendo el comercio con Inglaterra, pero este argumento

\footnotetext{
40 AGS, Contaduría del sueldo, segunda serie, legajo 117 (sin foliar).

${ }^{41}$ AGS, Estado-K, legajos 1.433 y 1.434.
} 
ya lo habían utilizado otros con anterioridad, aunque sin éxito, como en esta ocasión ${ }^{42}$.

La cuestión de las desobediencias e insubordinaciones de los ministros portugueses hacia los representantes castellanos no era nueva, ni se consideraba extraña en Madrid, pero resultaba de suma importancia resolverla porque de no hacerlo así el comercio con Inglaterra continuaría y la represalia quedaría sin efecto. De hecho, aunque se tomaron medidas rigurosas, los enviados a Portugal por los consejos de Hacienda y Guerra vieron obstaculizada su función desde el principio ${ }^{43}$. En julio de 1627 Pedro de Toledo, maese de campo y responsable de la gente de guerra en el Reino de Portugal, denunciaba cómo en la ciudad de Oporto entraba libremente todo género de mercancías, lo mismo que por el puerto de Aveiro se introducía en Galicia cantidad de vellón falsificado, sin que pudiera hacer nada para evitarlo. Por añadidura, el montante de los embargos realizados por Alvia de Castro multiplicaba, según sus cálculos, lo recaudado en Andalucía, pues solamente las 2.400 piezas de bayetas de Inglaterra aprehendidas en varios navíos procedentes de Hamburgo se valoraron en 165.000 ducados. A ello había que añadir lo procedido del contrabando en poder del mismo don Fernando de Toledo, que se elevaba a 164.511 reales ${ }^{44}$.

Los resultados obtenidos tras las primeras confiscaciones no dejan lugar a dudas de la diligencia de los agentes encargados de la represalia, incluyendo en este caso a los veedores de la Junta del Almirantazgo, ya que en menos de año y medio recaudaron al menos 250.000 ducados y consiguieron un bloqueo relativamente efectivo, a pesar de que el contrabando impidió el cierre hermético de los mercados de la Monarquía. Los problemas, empero, no tardarían en llegar. La falta de pescado fue denunciada con reiteración en Cartagena, Valencia, Alicante y el señorío de Vizcaya. La ciudad de Valencia representó la mucha falta que había en el Reino de vituallas, en especial del pescado salado que solían traer bretones, franceses e ingleses, de resultas de lo cual también se resentían los mercaderes que tenían empleadas sus haciendas en estos géneros. Por estas razones suplicaron a Felipe IV el permiso para que entrasen barcos de dichas naciones, no sin dejar de recordarle que a la ciudad de Valencia, por fueros y privilegios reales, le estaba concedida libre entrada y salida de navíos cargados con vituallas. Visto en el Consejo en noviembre de 1625 , pareció justo lo que se pedía, por lo que se dio permiso para introducir pescado de bretones y franceses «con que su procedido se sacase en frutos de la tierra, y no en oro ni plata» ${ }^{45}$.

Cartagena solicitó también permiso para que un barco francés cargado de sardinas de Irlanda pudiese entrar en puerto, argumentando que por él entraba

\footnotetext{
42 AGS, Estado, legajo 2.983.

${ }_{33}$ Los gobernadores explicitaban sin rubor que no cumplirían otras órdenes que las despachadas por el Consejo de Portugal.

${ }_{44}$ AGS, Estado, legajo 2.983 y 2.984

45 AGS, Estado, legajo 2.645, también en AGS, Guerra Antigua, legajo 3.149.
}

Hispania, LXV/1, núm. 219 (2005) 227-280 
todo el pescado salado que se consumía en Murcia y Toledo, y que debido a las prohibiciones, lo poco que había logrado introducirse había pasado a costar 66 reales el quintal, cuando su precio habitual antes de publicarse las prohibiciones no superaba los 24 reales. Por añadidura, sardinas no había en el mercado, y eran único pescado que podían consumir los pobres. A pesar de los argumentos a todas luces verosímiles, el Consejo de estado denegó la petición aduciendo que el pescado no era un mantenimiento que no se pudiera pasar sin él, y que en nuestros mares lo había de calidad; añadiendo finalmente que de abrir la puerta a los navíos de Irlanda entrarían los de Inglaterra ${ }^{46}$.

En el señorío de Vizcaya las reivindicaciones se dirigieron en otro sentido. Después de publicarse la prohibición del comercio con Inglaterra, algunos mercaderes de Bilbao que se encontraban en Bayona y San Juan de Luz pidieron licencia al corregidor de Vizcaya para introducir las mercancías que habían comprado de ingleses y holandeses antes del rompimiento. Otros las introdujeron clandestinamente, por lo que en el momento de comunicar estas novedades, se estaba procediendo contra ellos. Los primeros se sentían legitimados a pedir licencia precisamente porque su negocio consistía en llevar hierro y lana a las plazas francesas mencionadas, cuyo pago recibían en mercaderías de Inglaterra, las cuales navegaban luego a España. Prueba de su buena fe - argumentabanes que conociendo el paso fraudulento de Navarra, y aun a su más representativo contrabandista, llamado Juan de Zabalza, el tablajero de Navarra, abominaban de esas prácticas, las cuales incluso denunciaban. Los miembros del Consejo Pedro de Toledo, don Fernando Girón, el duque de Alburquerque y Duarte de Portugal tuvieron a bien permitir el paso de las manufacturas que aquellos mercaderes habían comprado antes de la prohibición, aunque únicamente las que no estuvieran prohibidas en España. Por el contrario, don Juan de Villela aseguraba que aquellos comerciantes pedían licencia por no haber podido introducir sus mercancías de forma encubierta, y juzgaba que había engaño, por lo que opinaba que el corregidor de Vizcaya había hecho bien en embargar ${ }^{47}$.

La inexistencia de instrucciones precisas sobre el modo de proceder en los embargos de esta represalia, a diferencia de lo ocurrido con la ejecutada contra los franceses aquel mismo año de 1625 , hizo que a los problemas ocasionados por la falta de abastos y el parón de la actividad comercial, se sumaran otros de índole competencial. Dirimir a quien correspondía el embargo de ciertas presas se convirtió con frecuencia en objeto de duras discusiones que hubieron de resolverse, tras pasar por la junta de represalia, en la pieza del Consejo de estado, por los marqueses de Montesclaros y la Hinojosa, el conde de Monterrey, Juan de Villela, el duque de Feria y Juan de Pedroso. En marzo de 1626 entró en Cádiz un patache inglés cargado de pescado y 32 fardos de mercaderías contra el que procedió el Alcalde Mayor de dicha ciudad. Si bien, cuando éste todavía

46 AGS, Estado, legajo 2.983.

47 Ibidem. 
se encontraba tomando las declaraciones al maestre, el factor Fernando de $\mathrm{Zu}$ rita reclamó el bacalao, afirmando que venía por su cuenta para la provisión de la Armada. Ahí acudió también el veedor del Almirantazgo, provisto de su secretario y varios guardas, reclamando la competencia exclusiva en materia de contrabando ${ }^{48}$.

La junta de Armadas reclamaba los pescados porque, era verdad, habían sido traídos por Zurita (factor) y Adrian Paez (mercader) con pasaportes firmados por don Fadrique de Toledo, aunque con la orden expresa del Rey, debido la necesidad que existía de bastimentos para la Armada. Tanto el Almirantazgo como el alcalde mayor reclamaban la causa, afirmando haber sido ellos los primeros en prevenirla: el inicio de las diligencias por uno u otro podía resultar el factor determinante para conseguir sustanciarla, ya que si bien el Almirantazgo tenía comisión para conocer todas las causas por contrabando y licencia expresa para decomisar los navíos ingleses, el alcalde tenía jurisdicción privativa en Cádiz y su puerto. El Consejo resolvió finalmente aplazar la consulta hasta comprobar quien de los dos había iniciado antes las acciones, y una vez conocido esto dictaminar lo que se estimase más conveniente.

Un último motivo de controversia se centró en torno a los irlandeses católicos, sobre si convenía o no permitirles el comercio con España. La cuestión surgió tras reclamar Diego Arthur y Juan Roch, mercaderes católicos procedentes de aquella isla, la devolución de lo que les habían confiscado en un navío tomado por presa por el capitán Villansen, en febrero de 1625. En el verano del año siguiente, el corregidor de Bilbao sentenció y dio por buena la presa del flamenco, y por su puesto la confiscación de bienes que implicaba; sin embargo, como quiera que Felipe IV había ordenado en febrero de 1626 que no se entendiese con irlandeses ni escoceses el embargo general decretado contra los ingleses, el Consejo revocó la sentencia del corregidor. No acabó ahí el asunto, ya que el Rey se vio obligado a no confirmar la revocación de la sentencia que proponía el Consejo, porque la presa había sido hecha en el mar, donde se había defendido peleando, y tanto el navío como la tripulación eran holande$\operatorname{ses}^{49}$. Por lo demás, la orden de permitir el comercio a los irlandeses y escoceses hubo de ser retirada en febrero de 1627 debido a que por medio de ellos entraban las mercancías de ingleses ${ }^{50}$.

Al contrario de lo que había ocurrido con los Holandeses antes y después de la tregua, o con los franceses a partir de 1635, no parece que en esta represalia se produjeran excesivos actos xenófobos contra la colonia inglesa en la Península. En Cádiz se tuvo presos a algunos súbditos de Carlos I con objeto de canjearles por españoles presos en Inglaterra; no obstante, dada su pobreza y falta de medios, se les liberó rápidamente porque nadie quería hacerse cargo de

48 AGS, Estado, legajo 2.983.

49 AGS, Guerra Antigua, legajo 927 (236).

so AGS, Estado-K, legajo 2.983.

Hispania, LXV/1, núm. 219 (2005) 227-280 
su manutención. Sólo quedó preso un tal Gil Espen, por ser un corsario de renombre, y con el temor de que hiciera fuga de la cárcel al ser ésta muy débilist. También se registró cierto entendimiento cuando el secretario de la embajada inglesa en Madrid, don Enrique Ati, pidió pasaporte para poder sacar de España los 4.000 ducados de plata y algunas alhajas más que le había dejado el embajador Walter Aston para llevárselas cuando fuera posible. La junta de represalias tuvo a bien conceder esta merced ${ }^{52}$.

El rompimiento se prolongó hasta noviembre de 1630, año en que Felipe IV y Carlos I firmaron un nuevo tratado de paz, confederación y comercio que reestablecía el tráfico comercial entre ambas coronas, con similares características a acuerdos anteriores: libre comercio de los súbditos de ambas coronas en todos los territorios de sus dominios correspondientes, «como lo fue antes de la guerra entre Felipe II e Isabel , y como se estableció de nuevo en 1604» es decir, excluyendo las posesiones de ultramar; imposibilidad de socorrer con bastimentos o pertrechos militares a los enemigos de uno y otro monarca; impedimento a los comerciantes ingleses de transportar mercancías españoles a Holanda, ni holandesas a España; y como novedad el establecimiento de un plazo de seis meses para que los súbditos de ambos monarcas pudiesen poner a salvo sus bienes y haciendas en caso de un nuevo rompimiento entre ambas coronas ${ }^{53}$.

\section{LA GRAN REPRESALIA DE 1635 CONTRA LOS FRANCESES}

Fue sin duda la represalia modelo, tanto por su alcance económico -la recaudación superó el millón y medio de ducados- como por su planteamiento inicial, su desarrollo y ejecución. Fue, desde el principio, una represalia sujeta a derecho, que se extendió por todos los rincones de la Monarquía Católica, y que logró el embargo hasta de las más ínfimas pertenencias de los franceses que se encontraban en los dominios de Felipe IV. Los resultados tan abultados de esta gran confiscación se debieron a la anticipación con que se preparó el embargo general ante un rompimiento a todas luces previsible, y sin embargo no se obtuvo más que una cuarta parte aproximadamente del capital que los franceses movían cada año en España. Esto fue debido a los avisos previos que el embajador Du Peny dio a sus compatriotas para que pusieran a salvo sus capitales, así como al desperdicio constatado en las operaciones de tasación y venta. Las directrices administrativas y ejecutivas que se siguieron en 1635 constituyeron un modelo de actuación que se utilizaría casi al pie de la letra en posteriores represalias. Tras la prohibición por parte del Rey Cristianísimo a sus súbditos de comerciar con España y la orden de embargo de los bienes de es-

\footnotetext{
51 AGS, Estado-K, legajo 1.434.

52 Ibidem.

53 Abreu Bertodano, op. cit. año 1630.
} 
pañoles en Francia en abril de 1635, Felipe IV ordenó la represalia contra los franceses por medio de una cédula real que explicaba los motivos que tenía para obrar así. Una vez dictado el embargo, se formó una junta de represalias con el objeto de organizar mejor las confiscaciones, y tras la formación de la junta se redactaron dos instrucciones sobre el modo de llevarla a cabo ${ }^{54}$.

Las instrucciones demuestran bien la voluntad para despojar a los franceses de todas sus pertenencias y expulsarles del comercio español, hasta el punto de convertir en delito de Lesa Majestad el trato mercantil con ellos. Además, los 24 puntos de la Instrucción sobre la forma en que se ba de ejecutar el embargo, y represalia, constituyen un espléndido ejemplo del estilo judicial y administrativo que exhibía la Monarquía Católica en el siglo XVII. En síntesis, el documento señala cómo había que descubrir a los franceses, solicitando a los escribanos de rentas las listas de los que pagaban alcabalas, e instando asimismo a exigirles los libros de contabilidad de sus negocios. La instrucción indicaba que de todo lo que se embargase había que hacer inventario, en presencia de sus propietarios, y después tasar los bienes por personas prácticas en ello, para seguidamente venderlos en pública almoneda. Se prohibía a extranjeros o a ministros vinculados al embargo la compra de lo subastado. Finalmente se advertía de que la ocultación de bienes de franceses o la no denuncia de su presencia sería castigada duramente. Otra instrucción explicaba la forma de dar salida a los bienes de franceses y ordenaba la venta inmediata de las pertenencias de los represaliados que de ninguna manera pudieran ser exentos del embargo (ya por poseer carta de naturaleza u otra razón similar) y en las cuales no hubiera una tercera parte interesada. Finalmente la norma exigía que el dinero obtenido se remitiera con la menor costa posible a las arcas reales 55 .

A comienzos de octubre de 1635 se mandó confiscar todos los navíos, pataches y demás bajeles fabricados en Francia, con sus cargas incluidas, que se apresaran tanto en los puertos como en el mar, y antes de que acabara el año ya se habían embargado, sólo en Sanlúcar de Barrameda, cuatro navíos, 19 tartanas y una saetía, todos ellos con sus aparejos y algunos con mercancías. Otros barcos fueron también confiscados en Sevilla, Cádiz, Málaga y Galicia ${ }^{56}$. En el mar, desde que estalló el conflicto hasta agosto de 1636, se habían capturado o hundido más de sesenta barcos franceses, la mitad de los cuales eran mercantes ${ }^{57}$. Si bien, una buena parte del embargo que se venía realizando consistía en bienes raíces, casas, censos y heredades del campo, pero sobre todo se buscaron sus capitales invertidos en el comercio, como se observa en el cuadro adjunto.

\footnotetext{
${ }^{54}$ Un análisis pormenorizado de esta represalia, en AllozA APARICIO, A., «El comercio francés en España y Portugal. La represalia de 1635» en Carlos Martínez Shaw y José María Oliva Melgar (eds.) El Sistema Atlántico Español, 1648-1828. Madrid, 2004 (en prensa).

55 Ambas instrucciones, en AGS, Contaduría del sueldo, segunda serie, legajo 154.

56 AHN, Estado, libro 716.

57 STRADl.ING, La Armada de Flandes. op. cit., págs. 137.
} 
VALOR DE LOS BIENES Y HACIENDA DE LOS MERCADERES FRANCESES DE SEVILLA Y SU TIERRA. 9 DE AGOSTO DE 1635.

\begin{tabular}{lcr} 
NOMBRE DEL MERCADER & $\begin{array}{c}\text { PLATA } \\
\text { (maravedís) }\end{array}$ & $\begin{array}{c}\text { VELLÓN } \\
\text { (maravedís) }\end{array}$ \\
\hline Pedro de la Farxa & 43.131 .552 & 38.661 .893 \\
Lanfran Davis & 25.155 .578 & 13.147 .882 \\
Pedro Alogue & 45.005 .225 & 19.722 .990 \\
Alberto Juan & 17.216 .782 & 13.739 .772 \\
Jacques Bulles & 6.057 .430 & 921.638 \\
Roberto Huber & - & 298.01 \\
Jacques Ramon y Roberto F. & - & 595.34 \\
Pedro Chacón & 305.413 & 2.915 .941 \\
Pedro Luy y Guillermo Clavier & - & 776.628 \\
Guillermo Grillo & - & 90.168 \\
Juan de Argubel & - & 2.176 .176 \\
Otros franceses & - & 12.628 .032 \\
Franceses de la Tierra de Sevilla & - & 4.037 .446 \\
\hline
\end{tabular}

Fuente: AGS, Contaduría del sueldo, segunda serie, legajo 154. Esta relación fue elaborada antes de producirse el desembargo de los cinco primeros a cambio de la composición que ofrecieron de 140.000 ducados.

DINERO PROCEDIDO DEL EMBARGO DE BIENES DE FRANCESES. REPRESALIA DE 1635.

\begin{tabular}{|c|c|c|c|c|c|}
\hline LUGARES & Plata & VELLÓN & LUGARES & Plata & VELLÓN \\
\hline $\begin{array}{l}\text { Ágreda y lugares de su } \\
\text { jurisdicción }\end{array}$ & 2.322 & 1.060 .068 & Madrigal & - & 385.118 \\
\hline Agudo & - & 694.926 & Málaga & - & 6.172 .308 \\
\hline Almagro & - & 401.392 & Mallorca & 3.958 .382 & - \\
\hline Almería & 5.611 & 418.574 & Martos & - & 32.438 \\
\hline Antequera & - & 156.094 & Menorca & 261.052 & - \\
\hline Aragón. & 4.000 .000 & - & Motril & - & 23.698 \\
\hline Aranda de Duero & - & 2.975 .000 & Murcia & - & 10.613 .176 \\
\hline Arjona & 一 & 13.134 & Nájera & - & 204.000 \\
\hline Ayamonte & - & 194.258 & Navarra y lugares & 26.271 .935 & - \\
\hline Baeza & 27.710 & 1.026 .238 & Ocaña & - & 85.000 \\
\hline Béjar & - & 1.104 .000 & Orán & - & 381.400 \\
\hline Buitrago & - & 1.098 .948 & Oviedo & 527.068 & 390.300 \\
\hline Bujalanze & - & 375.374 & Plasencia y lugares & - & 748.000 \\
\hline Burgos'y lugares & 14.380 & 3.743 .968 & Porzuna & - & 24.442 \\
\hline Cádiz y lugares & - & 15.810 .125 & Priego & - & 79.499 \\
\hline Calahorra y Bilbao & 170.000 & 2.505 .126 & Puerto de Gijón & 571.374 & 14.654 \\
\hline
\end{tabular}




\begin{tabular}{|c|c|c|c|c|c|}
\hline LUGARES & Plata & VeLLón & LUGARES & Plata & VELLÓN \\
\hline Cañete de las Torres & - & 1.192 .986 & Quesada & - & 105.581 \\
\hline Cartagena & 1.020 .000 & 3.400 .000 & Reino de Valencia & 112.500 .000 & - \\
\hline Cataluña y lugares & 5.810 .076 & - & Ronda & 5.800 & 946.166 \\
\hline Cazorla & - & 24.516 & San Clemente & - & 99.450 \\
\hline Cerdeña & 4.961 .416 & - & San Sebastián & 1.129 .926 & 7.541 .430 \\
\hline Ciudad Real & - & 374.000 & $\begin{array}{l}\text { Sanlúcar d Barra- } \\
\text { meda }\end{array}$ & 2.593 .388 & 17.312 .902 \\
\hline Córdoba y lugares & 10.098 & 6.200 .000 & Segovia & 7.650 & 8.889 .732 \\
\hline Cuenca y lugares & 6.154 & 355.078 & Sevilla & 53.552 .120 & 45.415 .714 \\
\hline Écija & - & 3.127 .219 & Talavera & - & 102.307 \\
\hline Galicia y lugares & 800.000 & 2.100 .000 & & & \\
\hline Gibraltar & - & 108.142 & $\begin{array}{l}\text { Tenerife, La Palma, } \\
\text { Veracruz e isla de } \\
\text { San Cristóbal }\end{array}$ & 9.248 .000 & \\
\hline Granada y lugares & 199.032 & 9.108 .232 & & & - \\
\hline Guadalajara y lugar. & 21.556 & 1.894 .534 & & & \\
\hline Guadix y lugares & 16.250 & 2.770 .918 & Toledo & - & - \\
\hline Ibiza & 143.514 & - & Torrejimeno & - & 43.288 \\
\hline Jerez de la Frontera & 41.208 & 948.766 & úbeda & - & 723.466 \\
\hline Laredo & 41.720 & 105.250 & Valladolid & 2.592 .000 & 5.135 .640 \\
\hline $\begin{array}{l}\text { Lisboa, Tercera, Pe- } \\
\text { nich }\end{array}$ & 17.698 .054 & - & Vélez-Málaga & 48.416 & 1.402 .956 \\
\hline Logroño & - & 2.203 .698 & $\begin{array}{l}\text { Villanueva de } \\
\text { Infantes }\end{array}$ & - & 3.140 .598 \\
\hline Lopera & - & 34.830 & Vitoria & - & 51.000 \\
\hline Lucena & - & 732.666 & Zamora & - & 27.181 \\
\hline Llerena & - & 846.200 & Total licencias & 95.797 .500 & \\
\hline Madrid & 2.696 .120 & 37.273 .541 & & & \\
\hline Madridejos & - & 3.979 .464 & $\begin{array}{l}\text { Montan las parti- } \\
\text { das: }\end{array}$ & 346.749 .832 & 218.448 .705 \\
\hline
\end{tabular}

Fuente: AGS, Contaduría del sueldo, segunda serie, legajo 151. (Balance hasta marzo de 1638)

A pesar de la preparación y la voluntad para que el embargo se efectuase de forma ejemplar, en Castilla, Aragón y Valencia la represalia dejó un poso de incertidumbre debido a los fraudes detectados, las ocultaciones deliberadas de bienes y las negligencias graves registradas en la contabilidad. En Cataluña muchos franceses se vieron libres de castigo, al ser considerados naturales por las autoridades públicas del Principado. En Portugal, la represalia fue un fiasco monumental: en palabras del oidor Francisco Leiton, miembro de la junta encargado de revisar los inventarios de la confiscación en aquel reino, «fue grande la omisión que hubo en hacer el embargo y ejecutar la cédula de Su Majestad». Es difícil imaginar un éxito rotundo de la administración del siglo XVII, pero a tenor de los datos disponibles puede decirse que la maquinaria administrativa del Seiscientos funcionó en esta ocasión a pleno rendimiento.

Hispania, LXV/1, núm. 219 (2005) 227-280 
Al margen de la recaudación obtenida, la represalia logró destruir la colonia de franceses radicada en la península y herir gravemente - aunque no de muerte- el comercio hispano-francés. En 1628 el embajador de Francia había estimado el valor total de la exportación de lienzos de algodón franceses a España en cinco millones de escudos de oro, resultantes de los 15 millones de libras anuales de tejidos que entraban principalmente por Sanlúcar, Cádiz y Sevilla. Quince años más tarde, en 1640, Pellicer estimó el capital francés en la península en tres millones y medio de pesos, de entre los siete y nueve millones de libras que entraban por Andalucía. Es lógico pensar que la guerra, la represalia y la prohibición del comercio fuesen los causantes de semejante descenso en las exportaciones francesas a España ${ }^{58}$.

Por el contrario, en un informe emitido por el Consejo de estado en enero de 1640 , con pleno conocimiento ya de los datos globales de la confiscación realizados por junta de represalias un año antes, éste se mostró muy escéptico acerca de la eficacia del embargo: confirmaba que había sido muy disminuido debido a que los ingleses habían asumido el papel de los franceses, no sólo camuflando sus haciendas y capitales, sino también retomando sus actividades comerciales. Lamentaba asimismo los resultados tan tímidos que se habían obtenido de la prohibición de comercio con Francia, y responsabilizaba de ello a las licencias y "permisiones particulares» que se habían dado para introducir géneros de aquel reino, así como al abuso que los portugueses habían hecho en los puertos de mar y tierra, enteramente bajo su dominio. El Consejo reconocía que las licencias se daban para reparo de mayores necesidades, pero entendía que esa práctica daba oxígeno a los franceses y les ayudaba a entretener la guerra, por eso aconsejaban su suspensión absoluta. El fraude en los fletes y despacho de navíos, donde se descubrían frecuentemente mercancías de Francia que se introducían con pasaporte de Hamburgo, Inglaterra y otras partes, así como el desinterés por la represalia en los puertos de Navarra y Aragón, donde «se entiende que no han tenido mejor cobro que los de Castilla", constituyeron para el Consejo de estado las razones de su escepticismo sobre la eficacia de las medidas de choque contra el rompimiento de Luis XIII ${ }^{59}$.

Como colofón, la necesidad de dinero para sostener los empeños de la guerra hizo emerger la idea de convertir a los franceses en contribuyentes forzosos, en vez de expulsarles de España. En 1638 una real cédula dispuso que fueran registrados y divididos en tres categorías fiscales: peones y oficiales en la primera, maestros en la segunda y mercaderes en la tercera. Mientras los primeros deberían en adelante pagar ocho maravedís diarios, los segundos tributarían 16 y los terceros 32. En enero de 1639 comenzó a recaudarse el nuevo impuesto,

s8 GIRARD, Le Commerce Français. op. cit., pág. 349.

59 Todas estas reflexiones del Consejo de estado en 1640 pueden verse en AHN, Consejos, legajo 7.119 (27). Hay que señalar que van muy en la línea del texto de Joseph Pellicer, Comercio impedido por los enemigos de esta monarquía. (1639). 
pero como ha apuntado Domínguez Ortiz, no dio demasiados frutos, ya que el escaso celo de las autoridades y el amparo de la población a los franceses lo impidieron, produciendo tan sólo 16.000 ducados el primer año de cobro y todavía menos en años sucesivos ${ }^{60}$.

La paz de los Pirineos, firmada el 4 de junio de 1659, puso fin al conflicto y reestableció el comercio que había sido interrumpido oficialmente durante 24 largos años. Por lo que se refiere a la represalia, el punto número 11 del tratado prescribía la restitución de las mercaderías y efectos embargados en uno y otro Reino, pero sólo en el caso de que se hallasen en ser, es decir que no se hubiesen vendido todavía, el día de la publicación del acuerdo. El capítulo XIII trataba de asegurar en adelante el comercio y amistad entre los súbditos de ambas coronas, acordando que si sucedía alguna rotura en el futuro se daría siempre seis meses de término a los súbditos de una parte y otra para que retirasen y transportasen sus efectos y personas donde mejor les pareciese.

\section{EL CIERRE DE LOS MERCADOS Y LA LUCHA CONTRA EL CONTRABANDO, 1625-1639.}

Las preocupaciones del Consejo de estado debidas a la introducción en España y Portugal de mercancías de enemigos en barcos de estados neutrales, podrían haberse visto atenuadas parcialmente si no hubiese existido una institución encargada de evitar el contrabando, pero lo cierto es que existía y además funcionaba razonablemente bien, lo cual no quiere decir que fuese capaz de cerrar herméticamente los mercados de la Monarquía, cosa por otra parte imposible, dado que por medio de las licencias especiales ella misma to impedía. En efecto, al objeto de evitar que los navíos de otras naciones introdujeran en España mercancías de países enemigos, el día 13 de enero de 1625 se creó la Junta del Almirantazgo, con sede en Madrid, y dependiente del Almirantazgo de los Países Septentrionales, creado un año antes en Sevilla ${ }^{61}$.

Por medio de las visitas e inspecciones realizadas por sus veedores, la Junta confiscaba y vendía aquellas manufacturas y géneros que su tribunal declaraba de contrabando. Existían grandes incentivos para denunciar el comercio ilegal,

${ }^{60}$ La gente lo denominó farda de los franceses, recordando el tributo que había pesado sobre los moriscos granadinos. Cesó en 1659 con la Paz de los Pirineos, pero se volvió a poner en vigor en 1667. DOMÍNGUEZ ORTIZ, A., Los extranjeros en la vida española durante el siglo XVII y otros artículos. Sevilla, 1996, págs. 78 y 79. (Edición dirigida por Álvarez Santaló).

61 Los fundamentos institucionales de este organismo pueden verse en DomínGuEz ORTIZ, A., «El Almirantazgo de los países septentrionales y la política económica de Felipe IV», Hispania, XXVI (1947), págs. 272-290; DE LA CONCHA, I., «El Almirantazgo de Sevilla. Notas para el estudio de las instituciones mercantiles en la Edad Moderna», Anuario de Historia del Derecho Español, XIX (1948), págs. 459-525; y DíAZ GonZÁLEZ, F.J., La Junta del Almirantazgo: Órgano de Gobierno y Tribunal de Apelación. Tesis Doctoral, Universidad de Alcalá de Henares, 1999.

Hispania, LXV/1, núm. 219 (2005) 227-280 
ya que el sistema de reparto de las confiscaciones se efectuaba por lo común en tres partes, una para el denunciador, otra para el juez o veedor, y la tercera para la Real Hacienda, representada por la Junta (las presas del corso solían repartirse en cinco partes). De modo que el incentivo a los denunciadores y la avidez de dinero por parte de los jueces y veedores, o en su caso corregidores, constituyeron un gran estímulo.

Los contrabandos provenientes de las provincias rebeldes $\longrightarrow$ de su transporte- entre 1625 y 1648 , de Inglaterra entre 1625 y 1630 , el de manufacturas textiles y otros productos de Francia a partir de 1635, así como el de Portugal a partir de 1641, constituyeron progresivamente el objeto de persecución por parte de los veedores de la Junta del Almirantazgo desde el comienzo de su andadura en 1625. Si bien, debido a la falsificación de las licencias de origen de las mercancías, la dificultad existente para distinguir las manufacturadas en Flandes de las producidas por estados enemigos, así como debido a su introducción fraudulenta en buques con bandera de conveniencia, las inspecciones de los veedores del $\mathrm{Al}$ mirantazgo se extendieron prácticamente a todos los barcos que arribaban en los puertos de la Península, vinieran de donde vinieran, porque de la misma forma que franceses e ingleses habían introducido manufacturas de Holanda antes y después de la tregua, los barcos de la Hansa no dudaron de transportar productos ingleses y franceses cuando su comercio con España se encontraba cerrado ${ }^{62}$.

Los ingresos registrados por don Francisco de Manzano, receptor de la Junta del Almirantazgo en Madrid, se componían de la tercera parte de las confiscaciones que por contrabando se realizaron en los puertos de mar, aduanas y puertos secos de la Península, entre 1625 y 1643 . Si bien, las partidas asentadas por este eficaz funcionario, cuya carrera como contador, receptor y tesorero en distintos organismos de la administración de la Monarquía se extendió durante más de 50 años, reflejan muchos otros conceptos que no se ceñían del todo a las confiscaciones, aunque todos ellos tenían que ver con el comercio ilegal, como fueron los relativos a composiciones e indultos por introducir ropa de contrabando, o los ingresos procedentes de la venta de los productos confiscados. Además, como se comprueba en la documentación examinada, no siempre la Junta recibió la tercera parte del importe de los decomisos, sino la mitad, dos tercios o tres cuartas partes de su valor, o a veces simplemente la cantidad que el veedor de comercio y contrabando tuviera a bien enviar a Madrid. Por estas razones, los cargos asentados por Manzano en los balances, aunque registrados con mucha claridad, constituyen un material muy complejo si se pretende interpretar con exactitud los criterios de la Junta en materia de distribución de las confiscaciones por contrabando ${ }^{63}$.

62 La actividad de los veedores y la recaudación de la Junta, pueden seguirse en ALLOZA APARICIO, A., «La Junta del Almirantazgo y la lucha contra el contrabando extranjero, 1625-1643", Espacio, Tiempo y Forma, Serie IV, 16 (2003) -en prensa-.

${ }^{63}$ Mucho más difícil todavía resulta calcular —a partir de estos ingresos- la proporción del contrabando en el volumen total del comercio exterior. Esto es debido entre otras cosas a las dife- 
INGRESOS DE LA JUNTA DEL ALMIRANTAZGO, 1626-1639.

\begin{tabular}{lr} 
AÑo & MARAVEDís \\
\hline 1626 & 2.945 .740 \\
1629 & 900.966 \\
1630 & 2.428 .037 \\
1631 & 7.785 .334 \\
1632 & 4.458 .544 \\
1633 & 9.720 .856 \\
1634 & 6.378 .238 \\
1635 & 6.096 .798 \\
1636 & 17.194 .290 \\
1637 & 11.005 .039 \\
$1638 / 39$ & 28.694 .922 \\
Total & 97.608 .764 \\
\hline
\end{tabular}

FUENTE: AGS, Contaduría del sueldo, segunda serie, legajo 162.

Los ingresos percibidos por Francisco de Manzano entre los años 1626 y 1639 son indicativos únicamente si se tiene en cuenta que las cifras suponen tan sólo un tercio del valor de los bienes de contrabando confiscados, y que los precios de venta de los productos decomisados estuvieron siempre muy por debajo de los que prevalecían en el mercado. De este modo, la suma de dinero que llegó a la Junta, elevada a 97.608.764 maravedís representa tan sólo la punta del iceberg del valor obtenido de las haciendas del contrabando confiscadas durante aquellos 15 años, ya que la cantidad pudo bien haber sido cinco o seis veces superior. Por otra parte, la cronología de los ingresos alteró asimismo la contabilidad de la Junta: la cuenta que se le tomó al tesorero revela que entre octubre de 1625 y marzo de 1631 Manzano recibió 35.835 .291 ma-

rencias tan abismales que hemos podido detectar entre los precios corrientes «o de mercado» de los productos de importación y exportación, y los precios a como se vendían los bienes confiscados por contrabando. En 1629 dos mercaderes flamencos residentes en Madrid, llamados Guillermo de Lovaina y Abraham Lerses, compraron 803 libras de especia de clavo confiscadas por el Almirantazgo al precio de 33 reales la libra, cuando su valor podía alcanzar en el mercado los 46 reales. En 1636 la Junta decomisó en Valmaseda una partida de especia de clavo que vendió a razón de 30 reales la libra, pero su precio en ese momento - según estimaciones de Hamilton- podría llegar a los 60,8 reales. Dos años más tarde, el corregidor de Agreda vendió 42,5 libras de ese mismo producto a un precio todavía más ridículo: 10,5 reales la libra. Con la pimienta confiscada ocurría lo mismo: las 159 arrobas y media incautadas del navío holandés que dio en Fuengirola en 1637, fueron vendidas a dos reales la libra, cuando su valor en Andalucía podía alcanzar los 12,7 reales. Los precios de las mercancías confiscadas, en AGS, Contaduría del sueldo, segunda serie, legajo 162. Los precios corrientes o de mercado, en HAMILTON, E.J., El tesoro americano y la revolución de los precios en España, 1501-1650. Barcelona, 1975.

Hispania, LXV/1, núm. 219 (2005) 227-280 
ravedís, cuando los envíos reflejados en la tabla se elevan a poco menos de 13 millones ${ }^{64}$. Entre septiembre de 1641 y marzo de 1643 Manzano registró un cargo de 15.754 .215 maravedís; finalmente entre abril de 1645 y abril de 1647 el tesorero recibió 17.220 .650 maravedís $^{65}$.

Existen casos que ilustran con claridad las lagunas registradas en la contabilidad de la Junta: a fines de 1628 el Almirantazgo se incautó de un cargamento importante de mercancías de contrabando proveniente de Francia, el cual superaba los 100.000 ducados y pertenecía a una conocida red de contrabandistas integrada por conversos portugueses, cuyos representantes eran Francisco Montesinos y Jorge Enríquez. Tras negociar con el Rey y el Consejo de hacienda una composición, no sin dificultades el Monarca acabó aceptando el donativo de 20.000 ducados y un préstamo de 100 mil ofrecido por los judíos, de cuyas resultas únicamente llegaron a la Junta 500 ducados, los cuales se habían reservado para pagar a los denunciadores de mercancías de contrabando ${ }^{66}$. Es decir, que de un ingreso de 20.000 ducados para la Real Hacienda promovido por el Almirantazgo, tan sólo llegaron a Francisco de Manzano 500 ducados.

Las cuentas de los representantes del Almirantazgo en Galicia, realizadas para el periodo 1628-1635 por Blas de la Concha, "pagador de la gente de guerra del Reino de Galicia y depositario de los contrabandos de él» reflejan espléndidamente las diferencias existentes entre el valor de lo que se arrebató a los contrabandistas y el dinero que finalmente llegó a la Junta de Madrid. De los 408.424 reales que importaron las haciendas embargadas y cobradas por el veedor Diego Portillo en Galicia durante el periodo mencionado, se destinaron a la Real Hacienda 159.727, de los cuales tan sólo 87.651 reales llegaron al final a Madrid, a poder de Francisco de Manzano. Bien es verdad que los cuatro navíos procedentes de Hamburgo incluidos en el contrabando de Galicia, nombrados San Miguel, Elector, Aguilanegra y Rey David, fueron condenados sólo en dos terceras partes, quedando la tercera absuelta ${ }^{67}$. Lo decisivo en todo

${ }^{64}$ AGS, Contaduría Mayor de Cuentas, tercera serie, legajo 400.

6s AGS, Contaduría Mayor de Cuentas, tercera época, legajo 3.483 y AGS, Contaduría del sueldo, segunda serie, legajo 117 respectivamente.

${ }^{66}$ Véase BelinCHÓN, «Sacar la sustancia del reino». Op. cit. págs. 1.036-1.044. Lo que ingresó la Junta del Almirantazgo por ese concepto, en AGS, Contaduría del sueldo, segunda serie, legajo 162 (año 1629)

67 Lo acontecido con esos cuatro navíos fue, sin embargo, muy grave, ya que intentaban pasar las mercancías con licencias falsas, siendo en aquellos momentos el comercio con Hamburgo muy fluido. Quizá por esa razón, los cónsules de las naciones flamenca y alemana, residentes en Andalucía, sirvieron a Su Majestad con 33.000 reales por los interesados en las haciendas de esos cuatro buques, «por haberles suplido los defectos de los testimonios con que venían las dichas mercaderías». Por otra parte, los registros de la Junta elaborados por Manzano muestran que tanto el veedor de Málaga, Pascual de Lezcano, como el fiscal de la Audiencia de Sevilla y juez asesor del Almirantazgo, Juan de la Calle, remitieron a Madrid durante 1636 y 1637 partidas correspondientes a los navíos Rey David y San Miguel por valor de 48.000 reales, la mitad de los cuales resultaba de lo obtenido por las tablas que venían en el Rey David. AGS, Contaduría del sueldo, segunda serie, legajo 162. 
caso fue que muy poco más de un tercio de lo aprehendido en la costa gallega arribó finalmente a la cuenta de Francisco de Manzano ${ }^{68}$.

Cabe reflejar también algunos casos de fraude detectados en la contabilidad, los cuales mermaron aún más — qué duda cabe- la cuenta de resultados, aunque hay que tener presente que estos casos no muestran únicamente el hecho de las defraudaciones, sino también que se actuaba contra ellas. El propio Manzano hubo de enfrentarse a varios alcances, de los cuales logró salir indemne: en el cargo del periodo 1625-1631 tuvo uno en su contra de 3.616 reales; en el comprendido entre 1633 y 1634 , se le descubrió otro desfase en sus cuentas de 8.144 reales ${ }^{69}$. Por su parte, el arrendador de los puertos secos del Norte, Juan de Zabalza, además de estar siempre bajo sospecha de fomentar el contrabando de portugueses, ingleses y holandeses, así como la saca de oro y plata a Bayona y San Juan de Luz, fue en más de una ocasión condenado a pagar multas considerables por introducir mercaderías de contrabando: en 1631 le confiscaron 11.907 reales, de los cuales tres cuartas partes fueron a la Real Hacienda. En 1636 fue don Jerónimo Pacheco, oidor de Valladolid y ex-gobernador de Asturias, quien se vio obligado a abonar 2.321 reales por el alcance que se le descubrió en sus cuentas de cuando el contrabando del Principado estuvo a su cargo. Del mismo modo, don Martín Nieto Trejo, alcalde de la Chancillería de Granada, no pudo evitar la multa de 7.614 reales debido a los alcances que tuvo un depositario nombrado por él, detectados en Málaga y Antequera. El Mercader granadino Antonio Montañés fue condenado en reiteradas ocasiones debido a las prácticas $\tan$ heterodoxas que realizaba en relación con los bienes confiscados: en 1639 fue condenado a pagar 11.000 reales por disponer de diferentes mercaderías de contrabando que le habían sido aprehendidas, y que se depositaron ien él mismo! sin orden ni licencia del Almirantazgo.

En síntesis, la cifra de 260.000 ducados depositada en manos del receptor de la Junta entre 1626 y 1639 , equivalente a cerca de un tercio del valor de las confiscaciones efectuadas en los puertos de la Península e islas Canarias, Azores y archipiélago de Madeira, exceptuando Cataluña y Reino de Valencia, muestra algunas luces y sombras sobre la lucha de la Monarquía contra el contrabando iniciada tras la reanudación del conflicto con las Provincias Unidas, las hostilidades con Inglaterra entre 1625 y 1630, y la ruptura con Francia en 1635. Desde luego, la suma podría haberse incrementado sin dificultad si se hubiesen vendido los bienes confiscados a precios aproximados a los corrientes, como podría haberlo hecho si se hubiese añadido a ella el valor de las mercancías decomisadas que en lugar de ser tasadas y vendidas fueron recuperadas por sus consignatarios previo pago de un indulto o de una composición, ya que en algunos casos los importes abonados por estos conceptos fueron ridículos, mientras en otros ni siquiera llegaron a la Junta. En 1636 Enrique de Andrade pagó

${ }^{68}$ Las cuentas del contrabando en Galicia, en AGS, Contaduría del sueldo, segunda serie, legajo 116.

69 AGS, Contaduría Mayor de Cuentas, legajo 400.

Hispania, LXV/1, núm. 219 (2005) 227-280 
25.767 reales por composición de los 33 fardos de ruanes que le habían aprehendido en Andalucía en un navío llamado San Jorge, sin embargo, ese mismo año, Juan y Gaspar Pasarinos desembolsaron 1.800 reales por un solo fardo de ruanes, es decir, el doble de dinero por fardo, a pesar de tratarse de una composición negociada con el mismo juez, Juan de la Calle. Pese a todo, la contabilidad de la Junta y la relación de mercaderes que con reiteración aparecieron condenados en ella evidencian que no se pretendía erradicar el contrabando, sino únicamente controlarlo, orientándolo a los intereses propios. Se avanzará más en esta idea en las siguientes páginas.

\section{LAS LICENCIAS ESPECIALES.}

Como se apuntó al inicio de este artículo, la necesidad de productos fabricados o transportados por el enemigo imposibilitó el cierre hermético de los mercados de la Monarquía. A comienzos del decenio 1620-30 resultaba todavía muy difícil prescindir del transporte holandés, especialmente el relacionado con ciertos productos destinados a la construcción naval, por eso aunque el comercio con las provincias rebeldes estaba absolutamente prohibido, en marzo de 1625 el Consejo de Guerra comisionó a Juan de Pedroso para que asentase con el Almirantazgo de Sevilla la introducción de 12 navíos holandeses con pólvora, jarcia, árboles, tablazón, alquitranes y plomo «permitiéndoles por esta vez que hagan la conducción de ellas por navíos fabricados en las islas de Holanda y Zelanda, como no sean holandeses los dueños de los dichos navíos, ni naveguen ni tengan parte en ellos». Seis buques habían de traer árboles, tablazón y madera, los restantes vendrían con pólvora, jarcia, cuerda, plomo, alquitranes, pacajes y otros aprestos de barcos, así como con buenas cantidades de cobre ${ }^{70}$. Se observa así que el inicio mismo del Almirantazgo, creado para combatir sobre todo el comercio holandés, y que preveía la construcción de 24 navíos de guerra, comenzaba dependiendo de aquel a quien se quería combatir.

La cuestión de las licencias se reveló entonces contradictoria. Las permisiones para introducir mercancías de contrabando evidenciaron la necesidad de productos manufacturados o transportados por los enemigos, cuyo desabastecimiento se producía precisamente a consecuencia las prohibiciones que se dictaban para comerciar con ellos. Pero estos problemas no se tomaron a la ligera, sino que se analizaron debidamente en los consejos de Estado y Hacienda. Una lección que se pudo obtener del análisis de esos contratiempos fue que, más que las licencias en sí, los inconvenientes surgían del uso y abuso que se hacía de ellas, y de la cantidad que se otorgaba, porque como reconocía el Consejo de hacienda, las licencias se daban sólo "para reparo de mayores necesidades» que la de impedir el comercio enemigo. Y no les faltaba razón a quienes así pensaban dentro del citado órgano: muchos beneficiarios de estas licencias especiales apa-

70 AGS, Guerra Antigua (Guerra y Marina), legajo 917. (Sin foliar).

Hispania, LXV/1, núm. 219 (2005) 227-280 
recieron registrados en más de una ocasión en la lista negra del contrabando. Pero antes de dar paso a esas discusiones llenas de contenido en la cumbre de los aparatos del estado, conviene conocer el alcance real de estas permisiones.

En septiembre de 1628 el Consejo de estado concedió al mercader flamenco Adrian Paez una licencia, previo pago de 60.000 escudos, para introducir mercancías por valor de un millón de escudos, en principio "de a 20 reales», con la condición de que dos tercios de los mismos habían de ser en municiones, bastimentos y pertrechos para las armadas reales. Además, en esta ocasión se autorizó el empleo de buques enemigos para el transporte de las mercancías. El Consejo de hacienda reprobó la medida por el mal ejemplo que daba a los naturales, argumentando que les disuadía de producir pertrechos de guerra cuando en España se daban en abundancia. Se lamentaba también de que al venir transportados en barcos enemigos, éstos aprovecharían para espiar nuestros puertos. Por añadidura, Hacienda estimaba que el presupuesto que tenía hecho Adrian Paez era de un millón de escudos de a diez reales, no de a 20, por lo que su contribución debería ser al menos de 200.000 ducados $^{71}$. Años más tarde, escudándose en la necesidad de dinero que existía en Cartagena para el sustento y embarcación de la gente de guerra que iba a ser transportada a Italia, Felipe IV dio comisión en noviembre de 1638 a don Luis Villagutierre, miembro del Consejo y oidor en la Chancillería de Valladolid, para que concediera licencias por valor de 150.000 ducados que permitieran traer a Castilla manufacturas francesas y alimentos, en especial ropa y bacalao.

El mercader inglés Benjamin Ruit, el mismo que financiaba las actividades lícitas e ilícitas de algunos compatriotas suyos en materia de contrabando, además de realizar asientos con Felipe IV, obtuvo entre julio de 1636 y octubre de 1638 licencias por valor de 950.000 ducados para introducir mercaderías, bastimentos y pertrechos de Francia, a cambio de 65.000 ducados, y a condición de que no se transportasen en navíos franceses ni por gente de aquel Reino. En los tres años que transcurren entre 1636 y 1638 se concedieron permisiones a otros comerciantes y hombres de negocios, entre los cuales muchos habían participado ostensiblemente en actividades de contrabando y comercio fraudulento, como Vicente del Campo, del comercio de Cádiz, Antonio Montañés, del de Granada; o los conversos portugueses Bartolomé Febo, Jerónimo de Fonseca o Pablo de Saravia. También había sido condenado el Flamenco Jorge Inqueldo, lo que no le impidió hacerse con una licencia de 150.000 ducados. Gaspar de Toledo, a quien se concedió una de 20.000 ducados para introducir mercancías de contrabando de Francia, acabó cediéndola a Benjamin Ruit. En suma, 4.388.000 ducados en licencias constituían una cantidad demasiado elevada que impedía interrumpir el flujo comercial con Francia, sobre todo si se tiene en cuenta que - como se vio anteriormente- hacia 1628 sólo las importaciones francesas de lienzos de algodón, según el embajador del Rey Cristianísimo, alcanzaban los cinco millones de escudos de oro, resultantes de los 15 millones de libras anuales de tejidos

${ }^{71}$ AHN, Consejos, legajo 4.424 (215); también en SHM, fondo Histórico, rollo 8, vol. 32.

Hispania, LXV/1, núm. 219 (2005) 227-280 
que entraban por Sanlúcar, Cádiz y Sevilla. Pero también es cierto que los 438.000 ducados que de ellas se obtuvieron para la Real Hacienda sirvieron al Rey Católico para continuar las hostilidades con Luis XIII ${ }^{72}$.

\section{LICENCIAS PARA INTRODUCIR MERCANCÍAS DE FÁBRICA DE FRANCIA, AÑOS 1636, 1637 Y 1638.}

\begin{tabular}{|c|c|c|}
\hline TITULARES DE LAS LICENCIAS & PERMISIÓN & INTERESES \\
\hline & (ducados) & (ducados) \\
\hline Bernardo Rodríguez y Julio Pérez (Sevilla) & 12.000 & 1.440 \\
\hline Juan Lorenzo Rato (Cartagena) & 10.000 & 1.000 \\
\hline Martín Ladrón de Guevara y Diego Cardoso* & 350.000 & 35.000 \\
\hline Martín de Longares & 50.000 & 6.000 \\
\hline Vicente del Campo y otros vecinos de Cádiz & 340.000 & 40.800 \\
\hline Jorge de Acosta & 6.000 & 720 \\
\hline Juan Lineta & 6.000 & 720 \\
\hline Bartolomé Scoto & 10.000 & 1.200 \\
\hline Francisco de Lineta & 10.000 & 1.200 \\
\hline Baltasar de Padilla & 4.000 & 480 \\
\hline Diferentes personas de Sevilla & 200.000 & 30.000 \\
\hline Alonso de Sierra y otros & 91.000 & 10.920 \\
\hline Antonio Montañés & 50.000 & 6.000 \\
\hline Alfonso Cardoso & 50.000 & 5.000 \\
\hline Benjamin Ruit & 950.000 & 65.000 \\
\hline Bartolomé Febo & 100.000 & 10.000 \\
\hline Blas de la Peña, Pedro Alogue y otros & 50.000 & 6.000 \\
\hline Francisco Gómez de Torres y otros & 721.000 & 86.520 \\
\hline Gaspar de Toledo & 20.000 & 2.000 \\
\hline Gerónimo de Fonseca y Pablo de Saravia & 160.000 & 10.000 \\
\hline Hombres de negocio de Sanlúcar & 100.000 & 15.000 \\
\hline Jorge Inqueldo & 150.000 & 15.000 \\
\hline Juan Díaz Jiménez & 80.000 & 8.000 \\
\hline Juan Ventura Tirado & 20.000 & 2.400 \\
\hline Miguel de Cáceres & 36.000 & 4.320 \\
\hline Nicolás de Peñalba & 20.000 & 2.000 \\
\hline Nicolás Franchot & 50.000 & 0 \\
\hline Nicolás Barresbique & 7.000 & 840 \\
\hline Pedro de Miranda & 35.000 & 3.500 \\
\hline Roberto Chan y otros & 240.000 & 28.800 \\
\hline Vicente del Campo & 61.180 & 6.016 \\
\hline Lo que montan las licencias & & 4.388 .000 \\
\hline Lo que ha tenido de beneficio Su Majestad & & 438.873 \\
\hline
\end{tabular}

FUENTE: AGS, Contaduría del sueldo, segunda serie, legajo 159.

72 AGS, Contaduría del sueldo, segunda serie, legajo 159 (sin foliar). 
El parecer del Consejo de hacienda con respecto a las licencias especiales, y aun con el modo en que se había llevado a cabo la represalia contra los franceses iniciada en 1635, la cual incluía como uno de sus puntos fundamentales la prohibición de comercio entre ambos estados, fue contundentemente contrario a la postura del Consejo de estado. Con motivo de la apertura del comercio que a fines de 1639 publicó el Rey Cristianísimo, el Consejo de estado estimó que debía cerrar todavía más el tráfico entre Francia y España «valiéndose Vuestra Majestad de permisiones particulares para traer a estos reinos lo necesario"; sin embargo los consejeros requirieron la opinión del Consejo de hacienda antes de elevar al Rey su propuesta. Hacienda interpretó la medida de Luis XIII de un modo distinto a como lo hizo el Consejo de estado, ya que según sus análisis la permisión dada por el Cristianísimo descubría los aprietos del Reino de Francia, debidos con toda seguridad a los clamores de sus naturales para el ajustamiento de la paz y el reestablecimiento de las relaciones comerciales, de las que aquéllos eran más dependientes. Por estas razones Hacienda postulaba el cierre absoluto de los mercados, así como la no concesión de licencia alguna; con lo que se daría a entender Luis XIII «que él no era el árbitro de la paz, ni de la guerra, ni del comercio, y que no dependía de su voluntad, sino de la de Vuestra Majestad» ${ }^{73}$.

El Consejo de hacienda aprovechó la ocasión para expresar su opinión general sobre cómo se habían llevado las cosas en la represalia de 1635 contra los franceses, y sobre cuestiones de mayor calado relativas al comercio exterior y su administración, en especial en lo que tocaba al papel que los conversos portugueses jugaban en él. Primeramente argumentó que las llaves de Castilla eran los puertos de mar y tierra, y que éstos estaban en poder de portugueses, quienes habían continuado el comercio como antes de la prohibición, es decir, como si nada hubiese ocurrido, de modo que si no se ponía remedio a esa situación el Cristianísimo dispondría de caudal suficiente como para mantener la guerra el tiempo que quisiera, y sus vasallos no sentirían nunca la descomodidad de la falta de comercio. Hacienda sospechaba que quitar los puertos a los portugueses que los tenían arrendados no iba a ser una tarea fácil, por lo que valoraba la idea de enviar a ellos inspectores capaces y responsables para que examinasen todo lo que entraba y salía de la Península, lo que remediaría la mayor parte del daño.

Hacienda también era consciente de la dificultad existente para averiguar el origen real de las manufacturas, al conocer que durante los años 1635 y 1636 los ingleses, «poniendo en sus cabezas las haciendas de holandeses y franceses» habían continuado el comercio, lo cual desvanecía el objetivo de las prohibiciones, de ahí que se hubiese comenzado a exigir a los mercaderes la posesión del libro público actualizado. Por añadidura, continuaba argumentado el Consejo de hacienda, desde el año 37, «y con pretexto de venir las mercaderías de Inglaterra y encaminar a aquel reino las de este, se habían negociado los productos de Francia a España, lo cual había sido debido a las licencias y permisiones

73 AHN, Consejos, legajo 7.119 (27). Todas estas ideas y análisis se hallan recogidos más pormenorizadamente en el memorial de Pellicer citado con anterioridad.

Hispania, LXV/1, núm. 219 (2005) 227-280 
que se habían dado, y siempre que se dieran sucedería lo mismo». Con lo cual el Consejo rechazaba de plano la concesión de permisos especiales, pues el daño que causaban era conocido y evidente.

Continuando su alegato contra las permisiones, el Consejo de hacienda demostraba que con una licencia de cien mil ducados se introducían mercancías por valor de 200.000 y más, porque estos permisos se daban a portugueses, y como los puertos estaban en su poder, la cantidad se regulaba a su voluntad «y así se tiene entendido que con ocasión de ellas se han metido en estos reinos sumas grandes de mercaderías». El Consejo reconocía que estas licencias se daban para reparo de mayores necesidades, pero por el efecto que de ellas se seguía era mejor no concederlas. Yendo incluso más lejos, los miembros del Consejo pidieron al Rey que revisase las que se habían dado hasta entonces, con el objeto de impedir el uso de las que ya estaban cumplidas y suspender las que quedaban por ejecutar. Sin embargo, no parece que Felipe IV siguiera los avisos que con tan contundentes argumentos le habían ofrecido los expertos de su Consejo, porque la expedición de licencias continuó su curso habitual, al haberse erigido en una buena vía de allegar recursos. Así, en 1642 Adrian Paez consiguió de nuevo una licencia por valor de 300.000 ducados para introducir en Castilla mercancías de contrabando, a cambio del adelanto del dinero suficiente como para comprar los caballos que se necesitaban para la Jornada de Aragón ${ }^{74}$.

Todavía a fines del decenio $1640-50$ se concedieron múltiples permisos para introducir mercancías, unas veces de contrabando y otras legales pero sin considerar apenas los estancos que había sobre ellas. El 23 abril 1649, Thomas de Santa Coloma, vecino de Bilbao, se obligó a pagar en octubre del mismo 12.150 reales «con que sirve a Su Majestad por la permisión para introducir 1.620 quintales de tabaco. Aquel mismo mes y año se permitió a Juan Jiménez Jurado, vecino de Málaga, introducir 10.000 quintales de bacalao de Francia, obligándose a pagar 2.400 ducados por la licencia. También en 1649, Guillermo Pauley, un conocido mercader y contrabandista de origen inglés, se obligó a pagar 12.000 ducados, para introducir por Bilbao y San Sebastián 100.000 ducados de azúcar, algodón, jengibre, tabaco y frutos que beneficiaban ingleses en las islas de Barbados, San Cristóbal y Virginia, pero con la obligación de traer testimonios auténticos de que eran frutos procedentes de ellas, y debiendo además ser consumidos exclusivamente en Vizcaya y Guipúzcoa ${ }^{75}$.

\footnotetext{
74 SANZ AYAN, C., «Negociadores y capitales holandeses en los sistemas de abastecimiento de pertrechos navales de la Monarquía Hispánica durante el siglo XVII», Hispania, 188 (1992), pp. 915-945, p. 932.

75 AGS, Contaduría del sueldo, segunda serie, legajo 117 (sin foliar).
} 
VIII. LA «REPRESALIA DE CROMWELL», 1656-1660.

Tras el triunfo de la Revolución Inglesa, la política exterior del Parlamento cambió por completo la trayectoria de sus relaciones con la Monarquía Católica. No obstante, la presión anti-española ejercida en Westminster por poderosos comerciantes de Londres se había visto incrementada al menos desde 1640. En diciembre de aquel año un nutrido grupo de mercaderes ingleses que traficaba en América demandó del Parlamento apoyo a un comerciante de tabaco llamado Joseph Hawes que había sufrido pérdidas por valor de 12.000 libras en un viaje a Virginia, debido a que su barco había sido capturado por la flota de Indias. Hawes había intentado recobrar sus pérdidas, vía represalia, de un barco español apresado cerca de las Bermudas, pero un agente al servicio de España lo impidió por medio de un juicio ganado en los tribunales de Londres, lo que enfureció y desanimó aún más a muchos mercaderes ingleses, sobre todo porque otros como Hawes habían sufrido pérdidas considerables en las mismas circunstancias poco tiempo antes. Este caso polarizó la atención del comercio de la metrópoli y en torno a él se organizaron todos aquellos mercaderes que tenían proyectos coloniales en América, logrando mantener vivas sus reivindicaciones en Westminster entre 1640 y $1660^{76}$.

No es casualidad que el memorial de agravios sufridos por los ingleses en el Caribe a manos de españoles; redactado por John Milton en 1655, fuera utilizado por Cromwell como casus belli para romper la guerra contra Felipe IV. El informe relacionaba todos los apresamientos efectuados contra los ingleses en aguas del Atlántico durante la primera mitad de la centuria del Seiscientos, "a pesar de los tratados de paz y comercio firmados en 1604 y 1630». Sólo entre esta última fecha y 1653 - apuntaba el escrito - se habían apresado barcos y cargamentos por valor de 102.000 libras, además de registrar un elevadísimo número de hostilidades, encarcelamientos, crueldades y asesinatos de colonos ingleses en diversas islas: 40 muertes en las isla de la Tortuga en 1636, cien en Santa Cruz en 1651, y muchos más en Barbados, Camanayota, La Habana, La Española... ${ }^{77}$

Por lo que respecta a Europa, no cabe duda de que la paz de Munster había supuesto una gran contrariedad para Inglaterra. Por lo pronto, la vuelta de la Monarquía Hispánica a la amistad con las Provincias Unidas en 1648 conllevaba un desplazamiento del comercio de ingleses con la Península, máximos rivales de los holandeses; pero en realidad aquel año tuvo una gran significación en términos geoestratégicos, ya que la paz acabaría alterando las alianzas y relaciones de poder en el Viejo Continente, desencadenando a su vez múltiples conflictos, como las tres guerras acaecidas entre Inglaterra y Holanda en el

76 BRENNER, Merchants and Revolution. op.cit. págs. 325-329.

77 Existe una traducción al español de este documento en AHN, Estado, Libro 872. véase también HARING, C. H., The Buccaneers in the West Indies in the XVII Century. Hamden, Connecticut, 1966, págs. 85-112.

Hispania, LXV/1, núm. 219 (2005) 227-280 
periodo 1652-1674, la firma de los tratados entre Inglaterra con Portugal en 1654, la alianza tres años más tarde con Francia contra los Habsburgo, y naturalmente la guerra contra España a partir de $1655^{78}$.

Oficialmente fueron el bloqueo del puerto de Cádiz y la toma de Jamaica entre 1655 y 1656 los acontecimientos que llevaron al rompimiento definitivo y a las subsiguientes represalias. Una escuadra del Parlamento solicitó a fines de 1654 varios bajeles de la Armada Real Inglesa que se encontraban en el puerto de Santander, y al ver su demanda rechazada por las autoridades locales, se presentaron enfrente de Cádiz treinta navíos de guerra ingleses. Tras varios meses de permanencia en aguas portuguesas, los almirantes Blake y Montague bloquearon la flota de dicha ciudad y merodearon por la costa andaluza, entrando luego en Málaga para causar graves daños y quemar algunos buques extranjeros. Su objetivo era el bloqueo del Atlántico ibérico y la captura de la flota de Indias, además de abrir una brecha en el Mediterráneo a través de Gibraltar ${ }^{79}$.

En septiembre de 1656 llegó al cabo de San Vicente la flota de Tierra Firme sin tener noticias del rompimiento inglés, continuó sin recelo hasta Cádiz, y al llegar a la bahía fue atacada despiadadamente. Dos mercantes lograron refugiarse en Gibraltar y el resto fue hundido o apresado, cediendo un botín, según los propios piratas, de dos millones de pesos. La flota de Nueva España no corrió mejor suerte, porque aunque tuvo aviso del peligro y tomó rumbo a las islas Canarias, donde fondeó sin problemas en Santa Cruz de Tenerife en febrero de 1657, al poco fue destruida por Blake, aunque al parecer los diez millones y medio de pesos que se dice transportaba fueron puestos a salvo en la fortaleza de la isla ${ }^{80}$.

La toma de Jamaica significó sin duda un duro golpe para Felipe IV, ya que se trataba de una conquista, sin previa declaración de guerra, que sentaba un incomodísimo precedente para la Monarquía Hispánica, al constituir la primera adquisición permanente de un enclave de la América española por parte de

${ }_{78}$ Naturalmente el ascendente poder comercial inglés contemplaba ya la inmediatez de la libertad de comercio en las indias. El conflicto con España, por añadidura, serviría a Cromwell para atraerse la amistad de Francia, la cual provocaría el retiro de su apoyo al Estuardo exiliado, el amedrentamiento a las Provincias Unidas, así como la defensa de Portugal frente a la Monarquía Católica. En definitiva, como ha destacado Valladares al hacer explícitas las consideraciones del secretario Thurloe, Gran Bretaña aparecería ante Europa como la nueva potencia protestante anti-Habsburgo. VALLADARES, R, La rebelión de Portugal, 1640-1680. Guerra, conflicto y poderes en la monarquía bispánica. Valladolid, 1998. págs. 140-149. Véase asimismo HERRERO SÁNCHEZ, El acercamiento bispano-neberlandés. op. cit. págs. 331-376.

79 INCHAÚSTEGUI, J.M., La gran expedición inglesa contra las Antillas Mayores. I. El plan antillano de Cromwell, 1651-1655. México, 1958. págs. 264-268 y 339-340; FERNÁNDEZ Duro, C., Armada Española. Desde la Unión de los Reinos de Castilla y Aragón. Vol. V, Madrid, 1885-1903, págs. 19-55. También puede verse HARING, C. H., Trade and Navigation between Spain and the Indies. In the time of the Hapsburgs. Cambridge, 1918, págs. 244-246.

80 Fernández Duro, Armada Española. op. cit. págs. 22-30. HARING, Trade and Navigation. op. cit. págs. 246. Goodman, R., Spanish Naval Power, 1589-1665. Reconstruction and defeat. Cambridge, 1997, págs. $27-28$.

Hispania, LXV/1, núm. 219 (2005) 227-280 
una potencia europea. Tras estos duros golpes el pesimismo se adueñó de la Corte de Madrid. Barrionuevo escribía: «Las Indias volaron, que ni las hemos de poder mantener, ni defendernos en nuestro rincón».

Todos estos acontecimientos forzaron finalmente la represalia mediante la aprobación de la pragmática de abril de 1656 - calco en las formas de la de 1635 - por medio de la cual se decretó la expulsión de los ingleses de los territorios de la Monarquía Hispánica, así como el embargo de todos sus bienes y haciendas, además de la prohibición de comerciar con súbditos de los reinos de Inglaterra, Irlanda y Escocia ${ }^{81}$. Al igual que ya ocurriera en 1635 con el Rey de Francia, en esta última sanción Felipe IV acusaba a los ingleses de haber movido una guerra injusta, sin denuncia previa, ni haber precedido los requisitos necesarios y acostumbrados en semejantes rompimientos. De este modo, la hostilidad unilateral del Parlamento legitimaba a Felipe IV a emprender acciones defensivas, y a defender y satisfacer a sus vasallos, así como a obtener recompensa por los daños que la guerra ocasionaría. Como en anteriores ocasiones, se nombró una junta y se dio comisión a diferentes ministros para efectuar los embargos en todos los dominios de Felipe IV ${ }^{82}$.

La Junta de Represalias de ingleses quedó formada el duque de Sanlúcar, el de Medina de las Torres, el Varón de Uchi, don Antonio de Vinania y Elazárraga, don Francisco de Solís Obando; don Miguel de Salamanca; don García de Porres y Silva; y finalmente a los señores don Fernández del Campo y Angulo, don Gregorio de Tapia, don Pedro de Aragón, don Fernando de Fonseca y Nicolás Rey. Se nombró a don Juan Ordóñez y don Francisco Paniagua y Zúñiga fiscales de la junta; Diego de Chavarría agente fiscal; tesorero a don Francisco Manzano; contador a don Juan González de Zárate; y como oficiales fueron designados Luis de Ugarte, Antonio de Rocas; como relator Antonio Canseco y como escribano a Juan de Miranda ${ }^{83}$.

La recaudación que se obtuvo tras el embargo de bienes de ingleses alcanzó la suma 9.136.049 reales, es decir, casi un millón de ducados, del cual más de la mitad se incautó en dinero líquido y el resto en deudas contraídas por comerciantes españoles o de otras naciones con los mercaderes británicos. Los valores reflejados en el cuadro adjunto, expresados en moneda corriente después de haber reducido los contadores la plata con un premio del 50 por ciento, no incluyen 48.000 reales que había pendientes de cobro en Madrid, y tampoco las cantidades recogidas en las ciudades de Barcelona, Mallorca, Cerdeña, Ibiza, Canarias, por no haber enviado las relaciones de los embargos realizados en

${ }^{81}$ AHN, Consejos, libro 1.241, ff. 112-117.

82 Un estudio más detallado de esta represalia, en AlLOZA APARICIO, A., «La 'represalia de Cromwell' y los mercaderes ingleses en España (1655-1667)» Espacio, Tiempo y Forma, Historia Moderna, 13 (2000) págs. 83-112.

83 AGS, Contaduría del Sueldo, segunda serie, legajo 161. 
ellas ${ }^{84}$. Por otra parte, a la junta le llegó un aviso afirmando no haber hallado bienes de ingleses en Aragón, Orán, Menorca, Navarra, Cartagena, Ronda y Guadix $^{85}$. En cambio, sí se embargaron las mercedes (rentas) que ciertos mercaderes ingleses gozaban en España; en concreto la junta se incautó de 412.794 reales de renta anual que gozaban 25 personas y cuatro instituciones ${ }^{86}$.

\section{CUENTA GENERAL DE LA REPRESALIA CONTRA INGLESES DE 1655.}

\begin{tabular}{lr} 
PROCEDENCIA & REALES VELLÓN \\
\hline Madrid & 826.058 \\
Reino de Valencia & 789.310 \\
San Sebastián & 252.824 \\
Bilbao & 136.959 \\
Santander & 60.800 \\
Asturias & 93.400 \\
Galicia & 257.498 \\
Cádiz & 1.498 .917 \\
Gibraltar & 9.000 \\
Málaga & 800.000 \\
Granada & 203.991 \\
Puerto de Santa María & 91.517 \\
Sevilla & 128.487 \\
Vélez y Fuengirola* & 45.054 \\
Canarias & 895.890 \\
Lanzarote & 44.000 \\
Sanlúcar de Barrameda & 2.612 .960 \\
Puerto Real & 95.900 \\
Mallorca e Ibiza & \\
Nápoles & 293.484 \\
Total & 9.136 .049 \\
\hline
\end{tabular}

FUENTE: AGS, Estado, legajos 2.981, 2.985, 2.986; y AGS, Contaduría del sueldo, segunda serie, legajos 158 y 161.

* incluye Almuñécar, Almería y Motril.

${ }^{84}$ Tampoco se recoge la cifra de 210.184 ducados aprehendidos en Nápoles, citada por Valladares, porque en nuestra reconstrucción de la contabilidad del embargo únicamente hemos encontrado el valor expresado en la tabla, que alcanza 293.484 reales. VALLADARES, La rebelión de Portugal, 1640-1680. op. cit. pág. 146.

85 AGS, Estado, legajo 2.986.

86 Algunas de esas rentas eran de por vida, otras por tres vidas y las menos a voluntad de Su Majestad, todas ellas situadas sobre las alcabalas de diferentes procedencias, millones de ciertas ciudades, sobre el 10 por ciento de las lanas, o sobre diferentes recursos reales como los diezmos de la mar. AGS, Estado, legajo, 2.989. 
OBLIGACIONES EMBARGADAS A LOS INGLESES EN CANARIAS, 1657.

\begin{tabular}{lc} 
REPRESALIADOS & $\begin{array}{c}\text { IMPORTE } \\
\text { (Reales vellón) }\end{array}$ \\
\hline Guillermo Jaque & 2.966 \\
Julio y Juan Carly & 9.588 \\
David Esteban & 31.748 \\
Thomas Bonisoy & 1.500 \\
Guillermo Clerke & 72.780 \\
Jorge Coque & 12.519 \\
Diego Thomas & 1.014 \\
Vanpiu & 5.450 \\
Ricardo Leprud & 10.030 \\
Enrique Negus & 77.408 \\
Thomas Esteplin & 1.768 \\
Thomas Borras & 13.062 \\
Joseph Lambel & 42.702 \\
.. Descoque & 2.341 \\
Isaac Orenton & 2.307 \\
Julio Campion & 45.177 \\
Thomas Colin & 9.953 \\
Thomas Jarle & 3.549 \\
D. Esteban y F. Bodies & 36.253 \\
Arthur Ingran & 31.851 \\
Ricardo Ely & 6.265 \\
Julio Chiele & 75.000 \\
Duarte y Fernando Bodie & 16.858 \\
Julio Guevar & 9.462 \\
Thomas Seldom & 1.971 \\
Mathias Calhajan & 2.533 \\
Leonardo Clerke & 10.034 \\
Marmaduque Random & 45.145 \\
Rolando Langran & 4.494 \\
Thomas Lucero & 2.400 \\
Julio Fauler & 600 \\
Fernando Bodie & 1.000 \\
Thomas Clayan & 4.958 \\
Juan Pintor & 15.938 \\
Roberto Breton & 1.936 \\
Isaac Cutton & 2.077 \\
Juan Carly & 6.501 \\
Juan Maquinel & 2.200 \\
Juan Guacinton & 473 \\
Thomas Fauler & 4.030 \\
Otros & 148.637 \\
Total & 776.479 \\
\hline Futr: AGS, Con & \\
\hline & 561 \\
\hline
\end{tabular}

FUENTE: AGS, Contaduría del suelo, segunda serie, legajo 161.

Hispania, LXV/1, núm. 219 (2005) 227-280 
Fueron unas cantidades ciertamente abultadas, aunque no tanto como las registradas en la represalia de franceses acaecida veinte años antes, pero tampoco la colonia inglesa era tan grande como la francesa. De todos modos, al igual que ya ocurriera en 1635, la represalia de Cromwell destruyó la colonia de mercaderes ingleses en España y redujo ampliamente el comercio bilateral. En este sentido, McLachlan afirmó que en el conflicto Inglaterra sufrió más que España, no sólo porque tenía mayor número de barcos destinados al comercio que su enemigo, y por tanto en peligro de captura, sino sobre todo porque el 90 por ciento del mercaderes que traficaban con el mundo hispano se fue a la ruina: se llegó a decir incluso que el comercio de ropa de Yorkshire se hundió a consecuencia de la guerra con España ${ }^{87}$. Por lo demás, un comité comercial inglés calculó en 1664 que sus mercaderes habían perdido un millón y medio de libras como consecuencia de las multas, imposiciones especiales y embargos ocurridos desde 1660, y que la pérdida de oportunidades de realizar contratos con el mundo español resultaba de valor incalculable, mientras las Provincias Unidas obtenían ahora enormes beneficios de la hostilidad anglo-española ${ }^{88}$.

En aquellas circunstancias no tardaron en elevarse duras críticas por parte de los hombres de negocios ingleses contra la política anti-española de Cromwell: al parecer la guerra contra España les había hecho perder no menos de 1.500 navíos de comercio. Lo cierto es que la importancia de los mercados de la Península Ibérica e Italia en la económía británica a comienzos de la segunda mitad del siglo XVII era extraordinaria. Más del 50 por ciento de las exportaciones del puerto de Londres se dirigían a los mercados mediterráneos, de las cuales España se llevaba el 45,2 por $100 .{ }^{89}$ La prohibición de comercio constituyó un verdadero golpe al comercio inglés en la Península, pero la propia represalia también causó graves daños, al llevarse por delante los negocios de importantes mercaderes que traficaban con España desde hacía décadas; nombres como los de Guillermo Pauley, Roberto Bretón, Ricardo Suit, Leonel Ubaque, Thomas Colin, Arthur Ingran, Marmaduke Ramdom y un largo etcétera se vieron despojados de sus bienes y expulsados de su actividad. Guillermo Pauley, por ejemplo, tenía 68 años al tiempo de la represalia y llevaba residiendo en Alicante desde hacía 58; casado con una mujer de aquella ciudad 40 años antes, declaró tener hijos y nietos católicos, bienes raíces, privilegios militares y cargos - como el de cónsul de su nación en 1638 - con objeto de que se le librara del embargo, al igual que habían hecho en la represalia de $1626^{90}$.

$\mathrm{Al}$ contrario de lo que pensaban en Inglaterra, algunos expertos en España creyeron que las represalias efectuadas reciprocamente habían sido más perju-

\footnotetext{
${ }^{87}$ MCLACHLAN, J. O., Trade and Peace with Old Spain, 1667-1750. A Study of the influence of commerce on Anglo-Spanish Diplomacy in the first balf of the eighteenth century. New York, 1974, págs:1-29.

88 STRADLING, R A., Europa y el declive de la estructura imperial española, 1580-1720. Madrid, 1983, págs. 219-223.

89 HERRERO SÁNCHEZ, El acercamiento bispano-neerlandés. op. cit. págs. 345-346.

90 AGS, Estado, Legajo 2.983.
} 
diciales para los súbditos de Felipe IV. Un informe visto en el Consejo de estado aseguraba que antes de romperse la guerra se habían secuestrado más de tres millones de pesos que los súbditos de la Monarquía Católica remitían al Norte, y que habiéndose pasado muchos oficios con el Parlamento, aunque ofreció restituirlos no lo hizo. A esta gran hostilidad se añadió la pérdida de más de tres millones de pesos que importó la plata, mercaderías y otros géneros de los navíos del cargo de don Juan de Hoyos, a la que siguió la otra gran aprehensión que hicieron las armas de Inglaterra en el cargo de don Diego de Elques, la cual si no llegaba a tres millones excedía de dos. A ello había que sumar los bienes embargados de los súbditos tanto de España como de Flandes e Italia en Inglaterra. En cambio, en España, el valor de los bienes confiscados a ingleses fue mucho menor, entre otras razones porque consiguieron poner sus haciendas a salvo justo antes de dictarse el embargo general, al tener por cierta la rotura de la guerra91.

Como en el resto de represalias estudiadas hasta ahora, los comerciantes y representantes de las corporaciones urbanas no dejaron de elevar sus quejas ante la merma de ingresos y abastos producidas por las prohibiciones de comercio. Desde Málaga, nada más iniciarse la represalia, representaron al Rey el interés de los vecinos de la ciudad en que no se interrumpiese el comercio con Inglaterra, y no sólo para que no les faltasen abastos, sino también para que los ingleses continuasen sacando los frutos de la tierra que desde antiguo se llevaban (pasas, vino..). También pedían que se permitiera la entrada de cinco navíos cargados de bacalao, ya que el trigo que Málaga compraba en el interior de Castilla lo pagaba con el pescado salado que importaba de la Isla. Finalmente, los malagueños argumentaban que, además del beneficio general de los vasallos, el comercio con Inglaterra producía enormes beneficios para las rentas de la Real Hacienda, en almojarifazgos, alcabalas, millones, «hasta en catidad de 700.000 ducados cada año de entrada y salida de este puerto", de modo que de faltar este comercio se seguirían pérdidas en los arrendadores y aun quiebras de dichas rentas, así como en los propios y arbitrios de la ciudad ${ }^{92}$.

Una real cédula publicada el 11 de septiembre de 1660 mandó reestablecer el tratado de paz, confederación y comercio de noviembre de 1630 , con lo cual se puso fin a la prohibición del tráfico y se inició una nueva etapa de relaciones oficialmente amistosas, consolidada en diciembre de 1665 con la ampliación de artículos al tratado de 1630 , así como la introducción de 16 secretos relativos a la tregua de Portugal. A pesar del bando de 1660 que mandaba hacer buen pasaje y tratamiento a los ingleses, el embajador Inglés en España — Ricardo Sancho- protestó por medio de un memorial redactado en 1664 como consecuencia de los malos tratos que sus compatriotas estaban sufriendo en España,

\footnotetext{
91 AGS, Estado, legajo 2.990. Véase también DomínGUEz ORTIZ, A., «Una relación de la pérdida de la Armada de don Juan de Hoyos», Archivo Hispalense, $46-47$ (1967) págs. 299-307.

92 AGS, Estado, legajo 2.989.

Hispania, LXV/1, núm. 219 (2005) 227-280
} 
especialmente en las Islas Canarias. También es cierto que la actitud del diplomático no era la más adecuada para exigir respeto a los mercaderes ingleses, ya que apelando al capítulo 23 de la paz de 1630 - que estipulaba un plazo de seis meses para abandonar el país con haciendas y bienes en caso de rupturadaba por nulos los embargos efectuados en la represalia y exigía la restitución de los bienes a sus antiguos propietarios ${ }^{93}$.

\section{REPRESALIAS CONTRA FRANCESES EN 1667 Y 1674.}

En 1667 se inició un nuevo periodo de hostilidades con Francia en cuyo transcurso se sucedieron rompimientos bélicos que desembocaron en represalias y embargos contra los súbditos de ambas coronas. Los resultados económicos de estas nuevas confiscaciones fueron escasos, pero no dejaron de entorpecer el comercio bilateral, obligado de nuevo a buscar refugio en el fraude y el contrabando, y de destruir el tejido comercial francés en las ciudades y puertos de la península. El recurso continuo a las represalias incrementó notablemente el nivel de su organización, mas no su eficacia, ya que la vacilación y tardanza a la hora de decretarlas posibilitó en más de una ocasión la fuga de los capitales franceses de las mismas fauces de la Real Hacienda, las más de las veces en connivencia con sus agentes españoles. Por desgracia, además, se constata que casi siempre acabaron pagando los pequeños y medianos comerciantes, incapaces de poner a salvo sus mercancías y escasos capitales, en contraste con los grandes mercaderes que disponían de información y conexiones necesarios para eludir los embargos. Como ejemplo, si en 1635 se pudo llegar a un acuerdo de composición con ciertos franceses acaudalados de Sevilla, en octubre 1667 la colonia francesa más pujante de Sanlúcar acordó con el presidente de la Casa de Contratación evitar el embargo de las partidas que venían consignadas a sus miembros en la flota de Indias a cambio de un regalo de 212.000 pesos $^{94}$.

Sólo cuando a comienzos de julio de 1667 las tropas francesas invadieron algunas plazas fronterizas de los Países Bajos españoles, con el pretexto de que pertenecían a Luis XIV por herencia de su esposa María Teresa, hija de Felipe IV, la regente Mariana de Austria ordenó la represalia contra los franceses, a pesar de que los movimientos del enemigo ya se habían detectado tiempo atrás, y a pesar también de que el Rey Cristianísimo había incumplido flagrantemente el tratado de los Pirineos desde el mismo día de su firma, al socorrer con armas y dinero a Portugal. Como quiera que el rompimiento francés se llevó a cabo sin previo aviso, y sin tratar de buscar solución pacífica a sus reclamaciones, y que además se habían producido algunas confiscaciones de bienes de españoles en Francia sin ajustarse al derecho de represalia, el Consejo de

\footnotetext{
${ }^{93}$ Ibidem.

94 GIRARD, Le Commerce Français. op. cit., págs. 260-334.
} 
estado pudo avalar el inicio de un embargo general de bienes de franceses, inminente y legal, no obstante el capítulo 24 de la paz de los Pirineos, que prescribía un plazo de seis meses a los súbditos de una y otra parte para que retirasen y transportasen sus efectos y personas donde mejor les pareciese en caso de iniciarse un nuevo conflicto bélico ${ }^{95}$.

Al igual que ocurrió en la de Cromwell, la represalia de 1667 se organizó bajo las directrices de la de 1635, a cuyas instrucciones se añadieron algunas nuevas, como el examen de los seguros marítimos, de los registros de los cargamentos con destino a América, o de los libros de los maestros plateros para evitar trasvases fraudulentos de plata, así como el reconocimiento de aduanas, y de los créditos que los franceses tenían con hombres de negocios en Madrid, Sevilla y otras plazas. No obstante su planteamiento estratégico y burocrático, Sánchez Belén y Ramos Medina han constatado que la mayor parte de los caudales de franceses que operaban en España logró salir indemne. La suma de los embargos realizados en Castilla, señorío de Vizcaya y Navarra apenas alcanzó la cifra de 90.000 ducados, contando el valor de los embargos realizados y las composiciones ajustadas con los muchos franceses naturalizados en España ${ }^{96}$. Mientras, el virrey de Aragón alarmaba de los peligros de ejecutar el embargo en aquellos dominios por lo mal defendidos que estaban y la más que probable resistencia a las confiscaciones de los muchos franceses que residían en ellos ${ }^{97}$. Fue una recaudación sin duda muy modesta teniendo en cuenta la amplitud de la colonia francesa en la Península Ibérica. Además, con la firma del tratado de Aquisgrán, en mayo de 1668, Mariana de Austria ordenó el desembargo y res-

\footnotetext{
95 «Y el capítulo 24 referido es muy conforme a lo que en todas las paces se dispone y se ejecuta en los rompimientos de la guerra cuando se procede con sinceridad, que es representar la pretensión o queja amigablemente antes de romper la guerra que no puede ser justa si no es en caso que se deniegue la debida satisfacción que no la pretendía el rey de Francia, pues habiendo V.M. respondido luego a su carta diciendo vendría V.M. en que se nombrasen personas de ambas partes para que se reconociesen los derechos que pretendía por la reina cristianísima con que se dejase el camino de las armas, no ha bastado esto para apartarle de su intento, antes al mismo tiempo comenzó a ocupar diferentes plazas y puestos (que estaban a la obediencia del rey nuestro señor) contra el derecho natural y de las gentes, siendo así que cuando su queja fuera bien fundada y tal la causa que bastara para llegar a semejante rompimiento había de preceder la denunciación necesaria de la guerra, y en este caso habiendo precedido las circunstancias referidas se debía ejecutar el conceder término de seis meses como se dice en el capítulo referido, no en el caso presente en que sin que precediese ... y denunciación de la guerra, que era tan preciso, antes al mismo tiempo que daba grandes seguridades el rey Cristianísimo en París..., invadió violentamente los Países Bajos habiendo pasado aun antes del rompimiento a hacer represalia de bienes de vasallos de esta corona de su orden por pretensiones de otros particulares de aquel reino. AHN, Consejos, legajo 7.269, $\mathrm{n}^{\circ} 29$. La organización y desarrollo de esta represalia, en SÁNCHEZ BELÉN, J. A. y RAMOS MEDINA, M. D., "Los comerciantes franceses en Castilla y la represalia de 1667» Espacio, Tiempo y Forma, serie IV, 7 (1994) págs. 287-318.

96 SÁNCHEZ BELÉN y RAMOS MEDINA, «Los comerciantes franceses en Castilla». op. cit. págs. $287-$ 318.

97 GIRARD, Le Commerce Français. op. cit. pág. 260.
}

Hispania, LXV/1, núm. 219 (2005) 227-280 
titución a sus dueños de todos los bienes confiscados en la represalia que se no se hubiesen vendido todavía.

No habían transcurrido cinco años desde la firma de aquel tratado cuando Luis XIV inició la invasión de Holanda, lo que dio origen a la formación de la Gran Alianza de La Haya en 1674 (Provincias Unidas, España, el Imperio, Brandeburgo, Lorena y algunos príncipes alemanes contra Francia) y por parte española al inicio de una nueva represalia contra los bienes de sus súbditos. En la pragmática que prohibía el comercio de los franceses en territorios de la Monarquía Católica, publicada en enero de 1674 , se hizo mucho hincapié en el cese del tráfico para impedir que Luis XIV se beneficiara de él y pudiera así continuar al guerra. Por esa razón se estableció también la pena de muerte a quien introdujese géneros de Francia o ayudara a hacerlo. En esta ocasión, no sólo se prohibió el comercio con el enemigo, sino que además se ordenó decomisar toda mercancía francesa, aunque perteneciera a españoles o estuviera en manos de aliados. La orden establecía, empero, un plazo de dos meses para que los tratantes pudieran deshacerse de los géneros franceses, previo registro, a fin de evitar el castigo de traficar con mercancías prohibidas. Como aviso final de la firmeza con que este nuevo embargo se quiso efectuar, se afirmó con rotundidad que no se daría licencia especial alguna para traficar con géneros del país vecino ${ }^{98}$.

Muchos mercaderes, principalmente los dedicados al comercio de la seda entorno a la Puerta de Guadalajara, en Madrid, y también los propios diputados de rentas de ese ayuntamiento, redactaron memoriales suplicando que el antedicho plazo de dos meses se prolongara durante un año, habida cuenta de que en invierno no tenían salida los tejidos de seda, cuya venta se producía en primavera y verano. El Consejo denegó su pretensión. De otra parte, los mercaderes de lonja flamencos solicitaron también la ampliación del plazo para la venta de las manufacturas provenientes de Lille, Tornay y Coutray, «ocupadas injustamente por el Rey de Francia en 1667», pero el fiscal lo denegó también afirmando que la suspensión del plazo perjudicaría la observancia de la pragmática y que además cabía el riesgo de que muchos mercaderes pasaran a los flamencos sus mercancías, imposible de distinguir unas de otras. Don Francisco de Soto Guzmán, encargado de averiguar las ocultaciones de bienes de franceses en Madrid, también representó la conveniencia de prorrogar el plazo, y lo mismo recomendó el embajador de Holanda aunque únicamente para los súbditos de los Estados Generales. La cuestión, no cabe duda, tenía su enjundia, y al final se dio un plazo de 18 meses de moratoria a los mercaderes de la Puerta de Guadalajara para colocar sus géneros extranjeros, y ocho meses a los del resto de Castilla, aunque previamente se les había concedido a todos ellos el permiso para pagar sus deudas

98 La pragmática referida, en AHN, Consejos, legajo 7.269, (29).

Hispania, LXV/1, núm. 219 (2005) 227-280 
en especie. En cambio, los fabricantes de sedas de la ciudad de Toledo pidieron al Consejo que no se entendiera con ellos la moratoria"9.

No cabía imaginar que la recaudación de esta nueva represalia fuera a ser muy elevada, teniendo en cuenta que muy pocos años antes se había producido otra de similares características contra los franceses. Quizá por ese motivo la pragmática de enero de 1674 se preocupó mucho más de reiterar la prohibición del comercio con el enemigo a fin de mermar sus fuerzas, que de resarcirse de las agresiones del ejército francés en los Países Bajos por medio de confiscaciones. A fines de agosto de 1675 ya se elaboró un primer balance que arrojaba un cargo a la tesorería de don Clemente Merino Romero de 22.085. ducados en vellón, 11.300 de plata en oro y 3.872 de plata blanca ${ }^{100}$. Si bien, el informe final que se redactó en 1690 mostró una cifra algo más abultada, además de destapar varios casos de fraude que con toda probabilidad aumentarían aún más la cuenta de resultados. El informe de 1690 arrojó la suma de 28.773 ducados de plata en oro y 28.832 en vellón ${ }^{101}$, a lo que habría que sumar 2.975 reales de plata y 1.494 de vellón que la junta de represalias exigió al depositario de los bienes embargados a franceses en la ciudad de Cádiz, al haber pagado en concepto de conducción de dinero a Madrid el seis por ciento, cuando lo normal en aquella fecha era el dos por cien; otros ocho o diez mil reales que podrían obtenerse de la venta de un navío llamado el Sol Dorado, que no habían subastado con la excusa de que sus propietarios tenían carta de naturaleza en España; y finalmente otros 12.000 reales provenientes de unas mercancías pertenecientes a un francés llamado Juan Turín, que había logrado —en connivencia con el depositario Francisco Velásquez - pasarlas como si fueran de contrabando ${ }^{102}$.

99 Todos estos memoriales y respuestas del Consejos pueden verse, en AHN, Consejos, legajo 7.269 , números $1,4,6$, y otros.

100 AGS, Contaduría del sueldo, segunda serie, legajo 155 (sin foliar).

${ }_{101}$ Ibídem.

102 Este último informe en AHN, Consejos, legajo 1.016.

Hispania, LXV/1, núm. 219 (2005) 227-280 
REPRESALIA DE FRANCESES EN CÁDIZ Y SU TIERRA EN 1674.

\begin{tabular}{lrr} 
BIENES EMBARGADOS & $\begin{array}{c}\text { REALES } \\
\text { plata }\end{array}$ & $\begin{array}{c}\text { REALES } \\
\text { vellón }\end{array}$ \\
\hline 1.055 quintales de bacalao & 59.080 & \\
cajas viejas de un navío & $4 \overline{-}$ & $19 \overline{7}$ \\
Madera de árbol y vela de una tartana & 116 & 6.254 \\
carga de una tartana & 6.400 & \\
Saetía doña Ana & 10.843 & $9.70 \overline{\overline{2}}$ \\
mercancías de la saetía doña Ana & 4.000 & - \\
Saetía Santa Ana & 1.600 & $1.11 \overline{0}$ \\
Saetía Santa Ana II & - & 880 \\
Bienes de Pierre Catalán, cónsul francés & - & 5.671 \\
Bienes de Pierre Magon & - & 1.043 \\
Bienes de Francisco Vidal & $74 \overline{8}$ & 8.020 \\
Bienes de Thomas de la Aya & 1 & 15.795 \\
Bienes de Pedro Navarro & 83.188 & 48.772 \\
Bienes de otras 46 personas & & \\
Total &
\end{tabular}

FUENTE: AHN, Consejos, legajo 1.016.

\section{DINERO CONFISCADO A MERCADERES FRANCESES POR MEDIO DE SUS DEUDORES. REPRESALIA DE 1674.}

\begin{tabular}{|c|c|c|c|}
\hline DEUDOR & REPRESALIADO & $\begin{array}{l}\text { REALES } \\
\text { PLATA }\end{array}$ & $\begin{array}{l}\text { REALES } \\
\text { VELLÓN }\end{array}$ \\
\hline & Roque Chalon* & - & 11.000 \\
\hline Antonio capillas & Pedro de Bans & - & 8.000 \\
\hline Sebastián Gutiérrez & & - & 98 \\
\hline Julio de Montejo & Pedro de Bans & - & 4.640 \\
\hline Manuel Sánchez Laso & Juan Antonio María Moliner & $5.689,5$ & - \\
\hline Domingo López & Moliner & 1.069 & - \\
\hline Domingo López & Pedro de Bans & - & 6.000 \\
\hline Carlos Fogosa & Pedro Treminer y Fco Cheron & 110 & 442 \\
\hline Juan Ortiz de Foronda & Moliner & $352(1)$ & \\
\hline \multirow[t]{2}{*}{ Juan de Aranguiz } & Pedro de Bans y Moliner & 341 & 4.950 \\
\hline & Pedro Escudero* & - & 11.000 \\
\hline Mateo de Zárate & Gil Girimón & - & 1.477 \\
\hline \multirow[t]{2}{*}{ Francisco Martínez } & & 1.216 & - \\
\hline & Juan Alonso Ontañón* & 9.600 & - \\
\hline
\end{tabular}




\begin{tabular}{llrr} 
DEUDOR & REPRESAliado & $\begin{array}{r}\text { REAles } \\
\text { PLATA }\end{array}$ & $\begin{array}{r}\text { REALES } \\
\text { VELLÓN }\end{array}$ \\
\hline Lucas de Adrada & Moliner & 15.247 & - \\
Pedro de Jáuregui & Pedro Balbes & 2.656 & - \\
Manuel Ignacio & Moliner & 4.500 & - \\
Simón Soriano & Moliner & 2.384 & - \\
Rodrigo Alonso & Moliner & 11.252 & - \\
Bernardo Belcos & Moliner & 8.080 & - \\
Joaquín de Ávila & Moliner & 16.362 & - \\
Juan de Santiago & & 52.789 & - \\
Antonio de Olano & Moliner & 5.500 & - \\
Gaspar de Encinas & Moliner & 32.782 & - \\
Joseph Ramón & & 1.600 & 9.960 \\
Sebastián Estambrero & & 415 & - \\
\hline
\end{tabular}

FUENTE: AGS, Contaduría del sueldo, segunda serie, legajo 155 .

Cuenta firmada por Juan González de Zárate en 21 de julio de 1681.

* indultados, pagan 1.000 ducados. (1) en oro.

La recaudación no alcanzó ni con mucho los niveles registrados en la represalia de 1635, pero no por ello dejó de tener cierta consideración, especialmente cuando se constata que en esta de 1674 la mayor parte del dinero se obtuvo en Madrid y Cádiz ${ }^{103}$, siendo el cargo incomprensiblemente marginal en los puertos del Norte, donde es sabido que se contrataban importantes sumas con los armadores franceses vecinos, y prácticamente inexistente en Cataluña, Aragón y Reino de Valencia. Por lo demás, los recursos al fraude tampoco fallaron en esta ocasión: la junta dé represalias tuvo noticia de que los mercaderes italianos residentes en Madrid «enviaban en letras con los correos de Flandes grandes cantidades que tocan a franceses» 104 .

De nuevo, como ya ocurriera en otros procesos de represalia, una buena parte de las confiscaciones de bienes y haciendas de franceses se consiguió por medio de sus deudores españoles, de aquellos pequeños y medianos comerciantes que se abastecían a crédito de manufacturas y géneros de todo tipo que introducían acaudalados hombres de negocios, desplegando una especie de putting-out system comercial. Además, a diferencia de otras ocasiones, el embargo de 1674 se efectuó en gran medida sobre la base de las denuncias de particulares, a quienes se beneficiaba con una cuarta parte de las cantidades confis-

103 En 1673 don Gonzalo Fernández de Córdoba, presidente de la Casa de Contratación, se encargó de la represalia en Andalucía. Subdelegó en Sevilla a don Tomás de Oño, fiscal de la Audiencia de Panamá y lugarteniente del asistente de Sevilla; en Sanlúcar a don Juan Tello y en Cádiz a don Juan Ignacio de Trujillo.

${ }^{104}$ AHN, Consejos, legajo 7.269, (2).

Hispania, LXV/1, núm. 219 (2005) 227-280 
cadas. El caso de don Cristóbal del Pozo Clavero es muy significativo al respecto, aunque a la vez muy especial, ya que a este señor se le mandó hacer de denunciador de diferentes personas que poseían bienes de franceses por valor de 166.000 reales de plata y 57.000 de vellón, con el fin de indemnizarle por la pérdida de 12.000 reales de a ocho que le habían confiscado a él en Francia, en el puerto de Colibre, cuando entró con un barco que provenía de Italia ${ }^{105}$.

Otro caso de denuncia con importantes revelaciones sobre el desarrollo de la represalia en San Sebastián, donde tan sólo se recaudaron 6.400 reales de plata en oro, a pesar de la importancia de su puerto para la introducción del comercio francés en Castilla, lo constituye el caso de Gracia de Atocha, una armadora vecina de dicha ciudad que fue denunciada por un tal Luis de Liñán y acusada por el fiscal de la junta de represalias de tratar y comerciar con franceses en tiempo prohibido, así como de ocultar caudales pertenecientes a ellos, en especial los de don Juan Casibila, un armador francés vecino de San Juan de Luz. En abril de 1675 doña Gracia de Atocha fue denunciada por introducir en el puerto de Pasajes un navío de fabricación francesa y perteneciente a franceses, por lo que fue embargado y mandado vender, aplicando la mitad de su valor a la Real Hacienda y los restantes dos cuartos al juez y denunciador respectivamente.

Sin embargo doña Gracia apeló al Consejo de Guerra y éste decidió devolver la embarcación a su propietaria tras observar que el barco no era sino el sustituto de otro que le habían confiscado a ella en Saint Maló tiempo atrás, con mil quinientas cargas de pescado, cuando regresaba de Terranova. Fiscal y acusador demostraron con nuevas pruebas la pertenencia de parte del navío a un francés, además de los negocios que la señora Atocha llevaba a cabo con Casibila durante el tiempo en que el comercio entre Francia y España estaba prohibido. Pero doña Gracia mostró estar dispuesta a luchar hasta el final para proteger su hacienda: cuando el juez que instruía el caso ordenó el embargo de sus bienes por no haber depositado la fianza que se le había exigido, se comprobó que la mayoría de ellos pertenecían ahora a su hijo Domingo, a quien se los había traspasado sin duda previniendo las consecuencias que sus tratos con franceses en tiempo de guerra podían acarrearle ${ }^{106}$.

A la vista de los resultados obtenidos, doña Mariana de Austria se lamentó de que la represalia no se hubiera ejecutado con todo el rigor que convenía según las leyes de guerra, al haberse dejado de embargar muchos bienes. Por esta razón, y con el fin de corregir los defectos en su ejecución, la regente, en un intento de completar la escasa recaudación que el embargo general había producido, reeditó en 1676 el recurso de la farda de franceses. A tal objeto siguió al pie de la letra la orden de 1638 mediante la cual se permitía a los franceses residir en España pero pagando un impuesto para gastos de guerra, que sería

\footnotetext{
${ }^{105}$ Hasta alcanzar los 12.000 pesos se le otorgó un tercio de las denuncias, pero todo lo que pasase de ahí se le retribuiría con un cuarto. AGS, Contaduría del sueldo, segunda serie, legajo 155.

${ }^{106}$ Una copia del resumen de las cuatro piezas que ocupó el pleito, en AHN, Consejos, legajo 1.016.
}

Hispania, LXV/1, núm. 219 (2005) 227-280 
de ocho maravedís al día los trabajadores, 16 los maestros de oficios mecánicos y 32 todos los demás. ${ }^{107}$ Un año después ordenó que todos los franceses que residían en los puertos se retirasen de ellos como mínimo 20 leguas hacia el interior. Al parecer la medida tuvo efecto, porque aunque algunos permanecieron en sus antiguas residencias, muchos otros las abandonaron y se dirigieron a Portugal y a Francia. ${ }^{108}$.

\section{BREVES CONCLUSIONES FinAles.}

Como se ha podido comprobar en estas páginas, las medidas de guerra económica que se adoptaron en el transcurso de todos aquellos años no fueron ineficaces, ya que cada una de ellas logró alcanzar mal que bien los objetivos básicos para los cuales había sido ordenada, que eran cerrar el comercio con la Monarquía Hispánica y resarcirse de las pérdidas ocasionadas por los rompimientos bélicos y robos y apresamientos indebidos por medio de los súbditos de los estados beligerantes. La represalia de 1625 contra los franceses provocó, aunque con muchas reticencias, la devolución de los cerca de 150.000 ducados secuestrados indebidamente por el duque de Guisa. La ejecutada contra los ingleses aquel mismo año, originada por una grave e injustificada hostilidad, les mantuvo cinco largos años alejados del comercio con España; un duro golpe si se tiene en cuenta que la vuelta a la amistad en 1630 tuvo más que ver con las presiones de comerciantes y manufactureros británicos para no perder el mercado español, que con la necesidad de bacalao y las quejas de los productores agrícolas andaluces. Otra cosa distinta, y discutible, es que las represalias fueran contraproducentes para la economía española; desde luego para los naturales que solían contratar con los represaliados, las consecuencias económicas fueron nefastas, al contrario que para los mercaderes y compañías que ocuparon su lugar.

Las represalias de 1635 contra franceses y 1656 contra ingleses fueron reacciones absolutamente predecibles, dadas las circunstancias de guerra rota. ¿Tiene sentido, entonces, preguntarse por la eficacia de las represalias en medio de rompimientos bélicos como los protagonizados por Luis XIII y por Cromwell? ¿Cabía la posibilidad de neutralizar las agresiones - al margen de la repuesta militar - por medio de otro tipo de acciones sin recurrir a las represalias comerciales? Por lo que se deriva de lo expuesto hasta aquí, parece fuera de toda duda que los bloqueos comerciales, en especial los efectuados contra los rivales que comenzaban a basar su poderío en el comercio marítimo mundial, constituyeron las respuestas inmediatas más predecibles y audaces dadas las circunstancias. Por lo que respecta al embargo de los bienes de extranjeros, las represalias se convirtieron en excesos difícilmente justificables, dado que lo

107 AHN, Consejos, legajo 7.119 (152).

108 GIRARD, Le Commerce Français. op. cit., pág. 267.

Hispania, LXV/1, núm. 219 (2005) 227-280 
procedido de las requisas apenas se utilizó para compensar las pérdidas sufridas por los españoles represaliados en Francia, Inglaterra o en otras partes.

Cabe también interpretar aquí el papel que el contrabando y las licencias especiales jugaron en el desarrollo de las represalias y las prohibiciones de comercio que provocaron. De los datos ofrecidos en el apartado dedicado al comercio ilegal se desprende que la lucha contra el contrabando estuvo encaminada a controlarlo, no a impedirlo, porque así se garantizaba el abasto de los mercados de determinados recursos cuando las necesidades apremiaban; y aún así, por muchos artículos que se introdujesen a espaldas de los veedores, o con su propia aquiescencia, no eran suficientes como para llenar los huecos producidos por las prohibiciones de comercio ${ }^{109}$. Por añadidura, cuando se necesitaban géneros como textiles para las Indias, o bacalao, trigo y pertrechos navales para la península, se expedían licencias que permitían contratarlos con toda garantía, salvando claro está los problemas ocasionados para transportarlos ${ }^{110}$. De resultas de todo lo cual se puede concluir que las medidas de guerra económica concebidas por los Austrias para neutralizar a sus más directos rivales en la carrera por el dominio del comercio mundial no fueron mínimas e ineficaces. El fracaso de su política por tanto deberá en buscarse en otras partes.

109 Herrero Sánchez también ha reflexionado recientemente sobre este fenómeno, y algunas de sus conclusiones confirman estos análisis. El autor apunta que los embargos no eran capaces de impedir la entrada de productos enemigos, pero sí servían para privilegiar a unas comunidades mercantiles sobre otras, siendo ahí donde radicaba en esencia el interés de tales medidas de bloqueos comerciales: «la Corona española - afirma- era consciente de que la viabilidad de la guerra económica aumentaba si lograba tener abastecidos sus mercados por un aliado capaz de cubrir la demanda». HerRero SÁNCHEZ, M., «La política de embargos». op. cit. pág. 181.

110 Como también ha observado Ildefonso Pulido, más que imponer una ruptura total del comercio con los enemigos, la Monarquía buscó un procedimiento que regulase las relaciones económicas con ellos, pero orientado a sus intereses. PULIDO BUENO, I., Almojarifazgos y comercio exterior en Andalucía durante la época mercantilista. 1526-1740. Huelva, 1993. 